\title{
Metamorfoses da Questão Geracional: 0 Problema da Incorporação dos Jovens na Dinâmica Social*
}

\author{
Adalberto Cardoso
}

Instituto de Estudos Sociais e Políticos (IESP) da Universidade do Estado do Rio de Janeiro (UERJ). Rio de Janeiro, RJ, Brasil. E-mail: acardoso@iesp.uerj.br

Varias generaciones viven en el mismo tiempo cronológico. Pero como el único tiempo verdadero es el tiempo vivencial, se puede decir propiamente que todas viven en un tiempo interior que, en lo cualitativo, es plenamente diferente a los otros (Mannheim, 1993[1928]:200).

\section{INTRODUÇÃO}

$\mathrm{K}$ arl Mannheim apresentou, em 1928, uma seminal (e ainda atual) discussão sobre "o problema das gerações", que o tomava como dimensão central de qualquer teoria da mudança social. Em suas palavras, o tema era "um dos guias indispensáveis para a compreensão da estrutura dos movimentos sociais e intelectuais" (Mannheim, 1928:522) ${ }^{1}$, "sem cujo esclarecimento não é possível compreender a história em seu devir" (ibidem:565)2 . Seu interesse residia tanto nos mecanismos pelos quais as sociedades incorporam as novas gerações na vida coletiva, procurando transferir a elas a herança cultural e simbóli-

\footnotetext{
* Este artigo é produto das pesquisas no âmbito do PRONEX-Juventude (www.pronex. iesp.uerj.br), financiado pela Fundação Carlos Chagas Filho de Amparo à Pesquisa do Estado do Rio de Janeiro (Faperj) e pelo Conselho Nacional de Desenvolvimento Científico e Tecnológico (CNPq). Agradeço muito especialmente os comentários de Wanderley Guilherme dos Santos a uma versão preliminar das ideias defendidas aqui. Agradeço também os comentários e sugestões de dois pareceristas anônimos de DADOS - Revista de Ciências Sociais.
}

DADOS - Revista de Ciências Sociais, Rio de Janeiro, vol. 58, n-4, 2015, pp. 873 a 912. 
ca herdada do passado e abrindo, nesse processo, espaço para a renovação dos horizontes culturais, normativos e cognitivos da vida em comum, quanto nos problemas resultantes da convivência, no mesmo espaço social, de diferentes perspectivas e orientações sobre aqueles mesmos horizontes, esposadas por gerações sucessivas.

Desde a publicação deste e de outros importantes estudos sobre o problema das gerações, surgidos antes ${ }^{3}$, o tema frequentou de muitas maneiras a teoria e a pesquisa social, assumindo novos conteúdos ao longo do século XX. Embora as perspectivas e os olhares sobre a relação entre as diferentes gerações que habitam o mesmo espaço social tenha mudado ao longo do tempo, uma ideia de fundo permaneceu, segundo a qual toda sociedade precisa se haver com o desafio da incorporação contínua de novos entrantes no fluxo populacional, que tensiona de muitas maneiras o tecido social.

Neste artigo, utilizando a discussão de Mannheim como fio condutor, proponho uma interpretação (curta como requer o espaço disponível) sobre as metamorfoses da questão geracional no mundo desenvolvido, com o objetivo de pôr em perspectiva a experiência brasileira e iluminar especificidades que julgo centrais para a compreensão de nossa dinâmica social mais geral e, principalmente, de nossos padrões de incorporação das novas gerações à vida coletiva. Para isso, na próxima seção recupero a discussão clássica de Mannheim e sua apropriação por Shmuel Eisenstadt nos anos 1950 e 1960, chamando a atenção para o viés fortemente normativo de ambas as construções do "problema das gerações". Esse viés mostrou sua face quando contraposto ao pendor totalitário de parte da juventude europeia (em suas versões "hitlerista", "fascista", "franquista" etc.) e também na crise social dos anos 1960 que, dentre outras coisas, revelou o descompasso entre as promessas de bem-estar, autonomia e liberdade da "era de outro do fordismo" (Boyer, 1995) e a realidade alienante da sociedade de massa.

Discuto, a partir disso, o caráter da socialização no mundo contemporâneo (e seu projeto republicano de equalizar oportunidades por meio de políticas públicas universais), e abordo algumas consequências da crise dos empregos para esse modelo de dinâmica intergeracional. E apresento, na seção final, uma interpretação sobre o padrão brasileiro de transição geracional, mostrando que o Estado esteve, sempre, muito distante dos mecanismos de estruturação das trajetórias sociais da maioria da população, que precisou construir por si mesma seu pre- 
sente e seu futuro em ambientes marcados por grande insegurança e vulnerabilidade socioeconômicas. Em suma, procuro contrapor o que considero um padrão eminentemente público (e republicano) de estruturação das oportunidades de vida das novas gerações, típico do mundo europeu, a outro, eminentemente privado (e mercantilizado), característico do Brasil, que estaria, porém, em processo de mudança nos últimos anos, ainda que muito lenta.

\section{RECUPERANDO UM TEMA CLÁSSICO}

Para cada geração, viver é [...] uma tarefa com duas dimensões, uma das quais consiste em receber o vivido - ideias, valores, instituições etc. - pela [geração] antecedente; a outra, deixar fluir sua própria espontaneidade (Ortega y Gasset, 1966[1923]:149).

Ao elaborar seu "problema das gerações", Karl Mannheim se interessou muito de perto pelo trabalho do historiador da arte Wilhelm Pinder, proponente, na Alemanha do início do século XX, de uma influente teoria geracional da arte (Pinder, 1926 apud Mannheim, 1928:516), segundo a qual a ordem social se caracterizaria pela "não contemporaneidade dos contemporâneos", isto é, pela convivência de várias gerações (e suas perspectivas, valores e aspirações, que constituíam, como queria Pinder, certo espírito de época) no mesmo espaço sócio-histórico. Do ponto de vista da teoria do conhecimento que propunha Mannheim, a renovação da cultura decorreria, dentre outras coisas, do fato de que as novas gerações não teriam por que viver a memória, os compromissos e os projetos das gerações passadas.

Para facilitar a compreensão do argumento, Mannheim usou um artifício engenhoso: levou o leitor a imaginar uma sociedade em que a primeira geração de homens (ele escrevia sempre no masculino) nunca morresse, nem novas gerações entrassem no fluxo populacional. Esta seria uma sociedade em que a tradição não precisaria ser ensinada, porque teria sido construída pelos contemporâneos. Nem a tradição sofreria mudanças importantes, a não ser que eventos inopinados (como guerras ou hecatombes naturais) exigissem novas descobertas, ou que os contemporâneos tivessem uma especial capacidade de abstração para abandonar sua posição confortável atual e idealizar utopias críveis. Nada disso, escreveu Mannheim, produziria transformações radicais na ordem. Estas demandariam novas gerações entrando continuamente no fluxo populacional, pois elas "nos ensinam a esque- 
cer o que não é útil, e a almejar o que ainda não foi conquistado" (Mannheim, 1928:533). E ele completaria: "uma espécie que vivesse eternamente teria que aprender a se esquecer de si mesma, e compensar a falta de novas gerações" (ibidem:535), sem o quê a vida em comum se tornaria insuportavelmente a mesma.

As novas gerações, para Mannheim, "portam" o novo não porque se organizam ou agem coletivamente para isso, por exemplo, propondo intencionalmente novos movimentos culturais ou correntes de opinião, novas enteléquias, como queria Pinder. Estas podem até se constituir, e a novidade bem pode emergir de movimentos assim, que configurariam uma unidade geracional, ou, se se quiser, uma subjetividade coletiva centrada (Domingues, 2002), ou consciente de sua unidade. Mas, embora ocorram com frequência, unidades geracionais não seriam as únicas responsáveis pela mudança cultural. As novas gerações, na verdade, introduziriam naturalmente e continuamente no fluxo da vida novos pontos de vista sobre a herança cultural, selecionando dela aquilo que lhes parecesse mais adequado a seus próprios anseios e aspirações, que seriam, sempre, testados e negociados com as várias gerações que convivem no mesmo tempo histórico. Nesse sentido, se é possível falar-se de um "espírito de época", ele seria o resultado da sobreposição das múltiplas enteléquias compartilhadas por diferentes gerações.

Mannheim escreveu seu clássico em meio à efervescência sem precedentes da juventude europeia, cujos movimentos coletivos estavam convergindo, voluntariamente ou de maneira forçada, e pelo menos desde o início dos anos 1920, para a Juventude Hitlerista, a Juventude Fascista, a Juventude Franquista e outras equivalentes ${ }^{4}$. Ou seja, enquanto ele escrevia sobre o papel renovador das novas gerações, o nazismo e o fascismo estavam mobilizando e militarizando os jovens em vários países, rumo ao totalitarismo e à guerra. Isso levaria Mannheim, mais tarde, a ponderar o tom claramente otimista da proposta de 1928. Durante a Segunda Guerra Mundial, na conferência "O problema da juventude na sociedade moderna", proferida em 1943 e publicada em 1952, ele pregou maior intervenção estatal na educação dos jovens, para evitar, justamente, que sua energia, que "está pronta para tudo o que há de novo" (Mannheim, 1952:62), fosse canalizada para a violência, o conservadorismo ou o totalitarismo.

De um tema central da teoria do conhecimento, a questão geracional (ou "o problema da juventude") se apresentou, desde logo, como um 
problema social. Mas a experiência nazista não levou Mannheim a rever sua percepção das novas gerações como transgressoras, apenas o alertou para o papel central que os mais velhos precisavam assumir na socialização dos mais jovens, muito especialmente em situações críticas ou revolucionárias.

Os movimentos da juventude alemã, é bom lembrar, por seu ineditismo já haviam atraído a atenção de muita gente, incluindo Max Weber, ele mesmo membro, desde sua própria juventude e até 1918, de uma fraternidade cujo código de honorabilidade assentava no duelo, portanto numa noção marcial de honra que era muito comum nos movimentos juvenis das classes médias e altas, para não falar nos que se originavam na aristocracia (os mesmos movimentos que, radicalizados, chamariam a atenção de Mannheim). Weber, como se sabe, proferiu duas importantes conferências para os jovens da Sociedade dos Estudantes Livres, e tinha verdadeira aversão à educação diletante e pacifista pregada por algumas fraternidades estudantis. Para ele, honra e responsabilidade eram valores que os jovens deveriam professar, e as escolas, ensinar. O libertarianismo de determinadas correntes estudantis e de parte do sistema escolar era visto como politicamente deletério, logo, como mecanismo desagregador, que não levaria a Alemanha ao destino desejado por ele, isto é, de país protagonista no concerto das nações ${ }^{5}$. Posição que, como a de Mannheim anos depois, reconhecia a centralidade da questão geracional na dinâmica social mais geral, ainda que eles não compartilhassem a mesma noção de honra ou de grandeza da Alemanha ${ }^{6}$. E o "problema da juventude", aqui, tinha a ver com a responsabilidade das gerações mais velhas na incorporação "adequada" dos jovens no fluxo da vida coletiva.

O tema, nesta chave propriamente conservadora, porque voltada para a integração regrada das novas gerações na vida social, continuou a interessar aos sociólogos. Num importante livro publicado em 1956, Shmuel Eisenstadt construiu abrangente teoria sobre gerações que deve ter surpreendido seus contemporâneos, ou ao menos aqueles que não compartilhavam de sua perspectiva analítica, funcionalista e centrada nos mecanismos integradores da sociedade ${ }^{7}$. O mundo, e muito particularmente a Europa, saíra havia dez anos de uma segunda guerra mundial, e a experiência europeia no entreguerras fora tudo menos "de paz". Os pretensos mecanismos coesivos presentes na teoria de Eisenstadt (como a família, as estruturas de parentesco e os rituais de iniciação nas sociedades "primitivas", a escola e as muitas ins- 
tituições estatais nas sociedades modernas), responsáveis por transferir a herança cultural e os padrões civilizatórios às novas gerações, haviam dado caldo de cultura, como já se mencionou, aos movimentos juvenis totalitários, sustentáculos entusiasmados de máquinas de guerra.

Eisenstadt operava com o corpo teórico e conceitual parsoniano. Conflitos e tensões sociais, nesse recorte, resultam da assincronia no funcionamento das instituições e subsistemas sociais, decorrente do processo de permanente diferenciação das esferas da vida, marca da modernidade. Eram vistos, portanto, como elementos centrais da mudança social, mas o interesse da teoria repousava sobretudo nos mecanismos que garantiam o sempre instável equilíbrio sistêmico, ou a coesão social. A juventude, momento crucial da experiência geracional, ganhava centralidade analítica. Contudo, em lugar de se ocupar da renovação dos horizontes da cultura, quase toda a construção de From Generation to Generation tinha por referência os problemas relacionados com as transições para a vida adulta e com o modo como diferentes ordenamentos sociais lidavam com o tema da socialização de pessoas aptas a "assumir plenamente seu status de adulto", ou de "pleno pertencimento à sociedade" (Eisenstadt, 2002:xxxii), socialização que se completaria, justamente, no período juvenil das gerações sucessivas, tendo na família e na escola os momentos principais.

Ainda assim, o Mannheim de 1928 e o Eisenstadt de 1956 compartilhavam uma imagem da juventude como um período de "moratória social", no qual ao indivíduo em processo de socialização era permitido experimentar, de maneira relativamente descompromissada, diferentes "papéis" antes de filtrar as escolhas que o habilitariam à vida adulta $^{8}$. Mas a experimentação deveria ser regrada, ou controlada pelas velhas gerações, o que torna um tanto estranha a insistência em noções como "criatividade social", "inovação", "abertura para o novo", encontráveis nos textos de ambos, ou a de que a juventude se identifica "com os valores e símbolos últimos da vida em comum", recorrente em Eisenstadt. Assim também, o Mannheim de 1943 compartilhava com o Weber de 1917 a ideia de que as energias juvenis precisavam ser domadas e direcionadas segundo objetivos definidos fora do indivíduo em processo de socialização, objetivos cujo horizonte deveria ser a democracia, a paz e o bem comum (e, para Weber, a honra e eventualmente a guerra em nome da honra), todos eles definidos na disputa política e civilizatória travada pelas gerações mais velhas, que estavam no poder 
nos diversos âmbitos de definição dos fins da ação pública, muito particularmente no aparelho de Estado.

Mannheim e Eisenstadt compartilhavam, também, a convicção de que a acolhida das novas gerações era aspecto decisivo da dinâmica social mais geral, por tensionar as estruturas mesmas de sustentação e reprodução da ordem. Isso porque raciocinavam num momento da história ocidental no qual as instituições modernas (não apenas públicas) eram vistas como centrais na definição das fronteiras e limites da experiência possível. Segundo esta percepção, as instituições (a família, a escola, o mercado de trabalho regulado por muitas instituições, a teia institucional estatal etc.), mesmo quando abertas ao novo e à criatividade, como é típico da modernidade, organizavam a memória social, formatavam as aspirações, desenhavam os objetivos possíveis, delimitavam os horizontes de expectativas, apontavam caminhos e organizavam os percursos da maior parte das pessoas, de tal modo que suas vidas podiam ser agregadas em coletivos significativos sobre os quais era possível tecer, com razoável previsibilidade, probabilidades agregadas de destino social". Ou seja, os mais jovens eram "acolhidos" no mundo das gerações anteriores pensado como um sistema relativamente unificado, cujas regras eram conhecidas (e compartilhadas pelos mais velhos, ao menos pela maioria deles) e podiam ser transmitidas pela socialização. Na "típica vida ideal de um mundo industrial intacto", como escreveu Ulrich Beck (2010:203), a família educaria para a escola, a escola educaria para o trabalho, o trabalho daria acesso à vida adulta, tipificada na constituição de uma nova família, fechando-se, assim, o ciclo da transição geracional. Nenhum deles pensava no problema das gerações como vazado por clivagens de classe, raça ou gênero. A trajetória típica, de cujo desvio poderiam resultar problemas sociais, era a do jovem homem branco de classe média.

\section{UMA CONSTRUÇÃO NORMATIVA}

Parece claro que boa parte dessas construções tinha inevitável viés normativo. Deveria ser papel das instituições modernas socializar os jovens para a democracia, a república, a honra e o bem comum, e também para o trabalho. Deveria ser sua tarefa transferir a herança cultural e as tradições, ainda que de forma aberta, permitindo espaço à criatividade social, à inovação, à mudança. O potencial contestatório da juventude deveria ser canalizado para a construção social, não para sua degradação ou destruição. E a tarefa das velhas gerações seria a de ga- 
rantir tudo isso, sem maiores sobressaltos, por meio das instituições que elas haviam herdado e que elas mesmas haviam transformado e modernizado com sua ação.

É curioso, nesse particular, que Weber e Mannheim escrevessem em meio à efervescência e posterior chacina de parcelas expressivas das novas gerações pela guerra, ou que Eisenstadt tenha publicado seu livro no momento em que a juventude socializada durante a Segunda Guerra estava começando a questionar os padrões culturais herdados do passado. Allen Ginsberg publicou Howl em 1956, inaugurando um movimento literário que revelaria o Jack Kerouac de On the Road (de 1957) e o William Burroughs de Naked Lunch (de 1959). Kerouac escreveu um livro autobiográfico, isto é, ele era um outsider vivendo experiências libertárias na estrada no momento em que Eisenstadt publicava seu livro sobre os mecanismos integradores da sociedade. Marilyn Monroe estrelara Niagara (em português, Torrente de Paixão) em 1953, e desfilara seu glamour pelo mundo promocional do filme com roupas curtas e decotes que, mais do que chocar as audiências e granjear a Norma Jean a fama de vulgar, sugeria que algo de novo estava em curso na transmissão intergeracional da moral puritana da família norte-americana, cuja hipocrisia era escancarada por seu comportamento sexual "escandaloso". James Dean morreu como um ícone em 1956, aos 24 anos, depois do estrondoso sucesso de East of Eden (Vidas Amargas) e Rebel without a Cause (Rebelde sem Causa), ambos de 1955 e ambos incendiários da cena cultural local e logo mundial, ao retratar uma juventude "transviada" e de futuro incerto. Elvis Presley estourara em 1955, e em 1956 já era um nome internacional, e encarnou o sonho americano de sucesso pelo talento, algo que também ajudara a construir a imagem e a aura de Monroe e Dean, mas bebia na música negra de seu país para criar um novo estilo musical que revolucionaria a música dali por diante, sacudindo os costumes e a herança cultural das gerações passadas.

Também em 1956, Françoise Sagan publicaria Un Certain Sourire, um clássico narrando a ansiedade e a angústia de uma jovem de 20 anos, amante de seu tio quadragenário e casado, num ambiente universitário (a Sorbonne) de grande liberação sexual. E Jean Paul Sartre e Simone de Beauvoir viviam um casamento aberto, tendo ela publicado o clássico feminista O Segundo Sexo em 1949, expondo as mazelas da condição feminina numa sociedade machista, um libelo libertário de grande acolhida em todo o mundo ${ }^{10}$. Esses exemplos da cena artística e 
cultural de meados dos anos 1950, muito mais rica e efervescente do que é possível enumerar aqui, foram tomados como "desvios" de conduta de "rebeldes sem causa", portanto, manifestações individuais "fora do padrão". Mas eles, na verdade, eram expressão de um mal-estar que, se ainda não explodira socialmente, seria transferido à geração seguinte, que faria a revolução cultural dos anos 1960.

A Europa, por seu lado, estava vivendo o sonho da reconstrução do pós-guerra. Estados fortes e uma institucionalidade robusta construída, dentre outras coisas, para conter a revolução socialista (Przeworkski, 1989; Korpi, 1983), estavam gerando bem-estar social para as massas trabalhadoras em escala sem precedentes. Isto é, os Estados europeus estavam consolidando os arranjos normativos que alguns denominaram "capitalismo organizado", outros, Estado de Bem-Estar, outros "sociedade salarial" e outros, ainda, simplesmente de "fordismo"11. E os países estavam mesmo moldando instituições voltadas para a integração das novas gerações, de maneira severa e re$\operatorname{grada}^{12}$, na modernidade fordista ${ }^{13}$. Parte dessa "severidade" (que também tinha um viés normativo, como mostraria o maio de 1968) era uma resposta ao passado totalitário de parcelas da juventude europeia. Se elas estavam prontas a "tudo o que há de novo", como queria Mannheim, cumpria lhes ensinar a ser humanistas, republicanas, democráticas, livres e eventualmente universalistas, além de criativas. Mas muito do que foi visto pela literatura como "norma" e "regra" escondia, como sugerido, o mal-estar que explodiria em 1968.

De fato, a década de 1960 jogaria por terra boa parte da aposta normativa das teorias sobre "o problema das gerações" e, principalmente, sobre a capacidade de as velhas transferirem a herança cultural às novas, ou de garantirem a elas trajetórias padronizadas e sempre ascendentes ${ }^{14}$. O maio de 1968 na França, que incendiou os países ricos neste e nos anos seguintes, não foi apenas uma revolta estudantil. Foi também uma revolta operária contra a modernidade fordista e seu padrão de exploração da força de trabalho. André Gorz, um dos muitos intérpretes daquele momento, escreveu, no calor da hora, que uma sociedade democrática não podia conviver com o despotismo vigente no mundo do trabalho, sobretudo na fábrica fordista, onde o trabalhador abria mão de sua cidadania ao trocar a roupa diária pelo macacão de trabalho (Gorz, 1973). Todas as teorias que haviam celebrado o "fim das ideologias" em razão da prosperidade fordista e do "fim do proletariado"15, também foram postas em questão pelo ressurgimento da luta de classes na Europa no fim 
dos anos 1960 e no início dos anos 1970, que resultou num grande ciclo grevista que só arrefeceria na década seguinte ${ }^{16}$.

Nesse ambiente novamente conturbado, Shmuel Eisenstadt voltou ao tema das gerações numa série de artigos, o mais importante dos quais argumentando que,

pela primeira vez na história, ao menos partes desses movimentos tendem a se tornar inteiramente dissociadas dos movimentos sociais ou nacionais mais gerais, do mundo adulto ${ }^{17}$, e tendem a não aceitar quaisquer associações ou modelos adultos - com isso expressando descontinuidade e conflito intergeracional sem precedentes (Eisenstadt, 1971:169).

Dentre outras coisas, o autor argumentou que os pais não teriam conseguido transmitir às novas gerações os significados dos traumas do passado (relacionados às duas guerras); sua "permissividade" teria aguçado a criatividade dos jovens; mas o mundo burocratizado e rotinizado teria frustrado essa criatividade e as expectativas criadas pelas promessas de liberdade e autonomia do "capitalismo organizado". Ecoando Mannheim, Eisenstadt dirá que os jovens não se sentiriam parte dos compromissos assumidos por seus pais, que resultaram na guerra e numa reconstrução que teria institucionalizado a revolução socialista em estados de bem-estar que, contudo, eram incapazes de cumprir suas promessas para os jovens, sendo um mundo burocrático fechado e controlado pelos mais velhos.

A avaliação do funcionalista Eisenstadt sobre o caráter burocrático da modernidade, que os jovens estudantes em 1968 teriam recusado, estava estranhamente em linha com a leitura libertária de Herbert Marcuse sobre as mazelas do capitalismo "unidimensional", militarizado, dominado pela ciência, pela técnica e pela razão instrumental, marcado pela prosperidade geral e pelo consumismo, um capitalismo "sem oposição" (Marcuse, 1964). Aliás, Marcuse e sua teoria crítica, mesclando Marx e Freud para propor a possibilidade de uma civilização não baseada na repressão da sexualidade (Marcuse, 1955), repressão que estava na base da interpretação de Freud sobre a origem e a natureza da civilização ocidental, seria um dos inspiradores dos revoltosos de 1968. Ele também refletiria sobre aqueles movimentos, em Contrarrevolução e Revolta (de 1972), buscando neles as possibilidades libertárias da nova revolução social. Os movimentos teriam mostrado a viabilidade de finalmente se reconciliar natureza e cultura, restaurando o 
caráter multidimensional da experiência humana. Claro que Marcuse não compartilhava do otimismo de Eisenstadt quanto à "pureza" da juventude e sua identificação com ideais últimos da sociedade, pureza que teria vindo à tona em 1968 para resgatar as promessas civilizatórias de liberdade e autonomia, soterradas pela burocracia. A revolução cultural que Marcuse pregava tinha no horizonte a reeducação dos sentidos dos jovens, socializados de maneira "unidimensional" na sociedade dominada pela técnica. Isso, obviamente, conferia um papel demiúrgico ao filósofo crítico, capaz de abrir as portas e guiar os jovens pelos caminhos da liberdade. Seja como for, ele se alinhava aos outros autores tratados aqui na percepção das novas gerações como depositárias da potência transformadora da sociedade, e contava com elas para radicalizar a transformação dos costumes e superar a opressão do capitalismo ${ }^{18}$.

\section{A SOCIALIZAÇÃO}

O sonho da incorporação regrada das novas gerações teve na escola seu instrumento mais importante. Em Paris, os movimentos de 1968 envolveram jovens educados, na infância e na adolescência, num sistema educacional público, de corte republicano, altamente centralizado e controlado pelo Estado, ainda que profundamente hierárquico. A esmagadora maioria dos filhos concebidos nos anos de guerra e posteriores recebeu uma educação que, embora destinasse as melhores escolas aos filhos das elites econômicas, era pública e gratuita. Os estudos de Bourdieu e Passeron (1964 e 1974) e Bourdieu (1979) não deixam dúvidas quanto ao caráter de classe das desiguais oportunidades educacionais dos franceses no sistema público de ensino ${ }^{19}$. Ainda assim, interessa ressaltar aqui (para efeito da comparação com o Brasil, mais adiante) o caráter público dos mecanismos de construção de hierarquias educacionais, o que quer dizer que, se nem todos tinham as mesmas oportunidades, as que haviam eram ordenadas por burocracias estatais (e também pelo sindicalismo docente e o séquito de profissionais da educação ligados ao poder público), que construíam e ensinavam a ideologia da educação republicana e igualitária. O sistema alemão também era profundamente hierárquico, e cabia à escola (portanto ao Estado, porque o ensino fundamental era e continua sendo quase exclusivamente público) decidir se o estudante tinha vocação para seguir o caminho da universidade ou do ensino técnico, decisão que era tomada pela escola, o que ocorria por volta dos 10 anos de idade do aluno. Este sistema foi em parte flexibilizado, mas ainda hoje a 
maioria dos 16 estados alemães (que têm autonomia para regular seu sistema educacional) controla rigidamente o percurso educacional das crianças e dos jovens, e as probabilidades de carreira ainda são decididas muito cedo em suas vidas. Na Suécia o sistema educacional era igualmente centralizado e controlado pelo governo e o parlamento (Miron, 1993).

Nesse quadro de centralização e de amplo controle estatal sobre os sistemas educacionais, era "natural" que o próprio Estado e seus agentes percebessem a socialização como inculcação da "civilização" nos corpos e mentes das novas gerações, que estariam predispostas, pela educação familiar, a recebê-la como uma espécie de "destino" imposto coletivamente, e pelo bem da coletividade. Mais do que uma tarefa dos mais velhos, o "problema das gerações" tornou-se responsabilidade compartilhada entre as famílias e o Estado, e este, desde muito cedo na Europa, tratou a educação como um direito de cidadania, que ganhou materialidade em políticas públicas educacionais que universalizaram muito cedo o acesso ao ensino fundamental e o Estado aparecendo como um dos agentes centrais da construção dos horizontes de expectativas dos mais jovens e da normatização de suas oportunidades de vida $^{20}$.

Se isso é verdade, os movimentos de 1968 em diante deveriam ter lançado imediatamente ao limbo as teorias da socialização das novas gerações que a viam como inculcação de valores, normas e padrões culturais (como em Eisenstadt), ou de internalização dos imperativos funcionais do sistema (como em Parsons, inspirador de Eisenstadt), ou de formação de indivíduos morais "ajustados" à ordem (como em Durkheim, antes deles). Se jovens de 1968, educados nas famílias e depois nas escolas (os ambientes "seguros" construídos pelas gerações anteriores), contestavam a ordem em suas múltiplas dimensões, da economia à política, dos costumes à religião, das ideologias às utopias $^{21}$, então, de duas uma: ou a família, a escola, o trabalho e mesmo o Estado não tinham "feito seu trabalho direito", já que passaram a ser vistos como mecanismos de dominação dos mais velhos sobre as novas gerações; ou a socialização como inculcação unidirecional de valores, ideologias ou pacotes cognitivos e afetivos, que partiria da sociedade e moldaria corpos, corações e mentes de indivíduos complacentes, precisava ser repensada.

Em 1991, depois de passar em revista as principais teorias sobre a socialização, de Piaget a Parsons, de Berger e Luckman a Bourdieu, de 
Mead a Weber e outros, Claude Dubar (1991), ancorado em Jean Piaget, propôs a ideia de que, numa sociedade moderna, democrática e aberta, a socialização é, antes, um processo dialógico, no qual os indivíduos em processo de construção de sua identidade social negociam o tempo todo com os códigos e conteúdos oferecidos pelas várias instituições (e pessoas) responsáveis por sua socialização, isto é, as gerações passadas. A "sociedade" não pode ser pensada como uma unidade coerente cujos conteúdos possam ser sistematizados de modo a serem "inculcados" também de maneira coerente e unitária nas mentes e nos corpos das pessoas. Um processo de aprendizado é sempre múltiplo, os pais precisam aprender a ensinar, e frequentemente aprendem com os próprios filhos, que impõem limites, apontam alternativas, sugerem caminhos para sua educação ${ }^{22}$. Mais do que tudo, o processo ocorre em múltiplas esferas da vida, muitas delas com códigos próprios e não redutíveis uns aos outros, de tal modo que a pessoa em formação precisa construir ela mesma a unidade que será sua identidade social, sempre de modo ativo, e também infindável, já que a socialização não é algo que se encerra quando o indivíduo atinge "a maturidade plena", como queria Eisenstadt. As "idades da vida" (Mauger, 2013) são também idades de constante aprendizado, portanto, de constante socialização.

Esta concepção do processo socializador supõe que, mesmo a ideia central por trás da noção de "maturidade plena", isto é, a de que o indivíduo, a partir de certa idade, é capaz de ação autônoma (pelo quê se deve entender capacidade de manter-se por si mesmo e de julgar as consequências dos próprios atos ou omissões, e ser responsável por eles), mesmo isto não se adquire de uma vez para sempre. $\mathrm{O}$ mundo contemporâneo, globalizado, é mais aberto do que nunca, mas as competências (e a autonomia) adquiridas numa parte do planeta não servem necessariamente para o lugar no qual, por exemplo, o indivíduo migrante decide escolher para viver (caso consiga migrar) (ver Beck, 2010:cap. 5). Um acidente ou a guerra pode obrigar a pessoa a reaprender a viver numa cadeira de rodas ou sem um membro. Traumas emocionais podem ter efeito semelhante etc. Migrações do campo para a cidade num país como o Brasil também requerem o reaprendizado da vida em comum, como veremos. Além disso, escolhas ocupacionais ocorrendo muito cedo na vida dos jovens, num ambiente sempre mutante em termos de oportunidades de emprego, estenderam, e muito, o período de qualificação para o trabalho, sendo cada vez mais comum, 
por exemplo, o retorno aos estudos depois de repetidas frustrações ocupacionais (Larue et al., 2009).

\section{DE VOLTA AO PROBLEMA GERACIONAL}

É claro que o pós-1968 e a renovação da compreensão sobre o processo socializador ${ }^{23}$ não tornaram obsoleta a discussão sobre o "problema das gerações". Se a socialização dos mais jovens não pode ser vista como um movimento unidirecional da "sociedade" para o indivíduo ${ }^{24}$ (compreensão que, por sinal, já estava em Mannheim), ainda assim continua sendo tarefa das gerações presentes acolher as novas no fluxo populacional, oferecendo a elas (e criando com elas) oportunidades e condições para o eventual exercício futuro da liberdade e da autonomia, ainda que, no capitalismo cada vez mais globalizado, estas continuem promessas sempre longínquas, e não estejam igualmente distribuídas segundo as classes sociais.

Na verdade, a partir de meados da década de 1970 o "problema das gerações" foi reposto, agora com novos significados, de maneira dramática pela reestruturação neoliberal do capitalismo, que se seguiu à crise do arranjo fordista. A reestruturação inaugurou, de maneira surpreendente, uma nova era de incertezas e de insegurança socioeconômica para as gerações contemporâneas da crise. Isso porque a reestruturação (aprofundada nos anos 1980) trouxe de volta algo que se julgava sepultado pelo "capitalismo organizado": altas taxas de desemprego, e este se tornou novamente longo e continuado, quer dizer, estrutural, principalmente para os mais jovens. Se, antes, o "problema das gerações" estava relacionado com a negociação intergeracional de horizontes de expectativas, padrões culturais, valores etc., a partir dos anos 1970 aqueles horizontes se tornaram opacos para parcelas crescentes dos mais jovens.

Na emblemática França, parteira das revoltas de 1968, o desemprego de pessoas na faixa etária de 15 a 24 anos saltou de 5\% em 1970 para $14 \%$ em 1980 . Na Itália, de $10 \%$ para $16 \%$. Na Alemanha, com seu sistema educacional segmentado, que garantia emprego imediato aos que deixavam a escola, o salto foi de $0,4 \%$ para quase $4 \%$, e de $11 \%$ a $14 \%$ nos Estados Unidos. Na Espanha o desemprego juvenil já atingia $28 \%$ em 1980, tendo saído de 12,4\% em $1977^{25}$. E a cifra atingiu espantosos $47 \%$ em 1985 . Neste mesmo ano, $18 \%$ dos jovens ingleses, $10 \%$ dos alemães e $20 \%$ dos franceses estavam desempregados, segundo a mesma 
fonte. Completar os estudos, mesmo no caso do ensino superior, já não significava encontrar um emprego, aumentando, assim, a ansiedade tradicionalmente associada às escolhas profissionais.

Ao lado disso, já no começo da década de 1970 a literatura identificava (e louvava) o processo de massificação da educação superior nos países ricos ${ }^{26}$, que continuaria pelos anos seguintes. A França tinha mais de meio milhão de universitários em 1968, e em 1975, 20\% dos jovens em idade universitária a estavam cursando. A taxa era de $25 \%$ na Suécia, 32\% no Canadá e 40\% nos Estados Unidos (Kerr, 1991:100). Mas na aurora da década de 1980 e depois, o processo antes saudado como alvissareiro, tendo em vista a clara associação entre escolaridade e oportunidades de vida e trabalho ${ }^{27}$, passou a ser lido como "inflação de credenciais", que estaria reduzindo de forma crescente os retornos monetários dos diplomas universitários, que deixaram, também, de assegurar acesso imediato a um emprego ${ }^{28}$. Tornou-se comum, no ambiente incerto criado pelo neoliberalismo dos anos 1980 e 1990, a expressão "educação para o desemprego". Ainda era melhor ter um diploma do que não ter, em termos de oportunidades de trabalho e renda, mas ele não era mais uma chave universal, sobretudo num mercado de trabalho em rápida transformação, que terminaria, com o tempo, por desvalorizar algumas credenciais.

Desde então o problema só se acentuou. A Tabela 1, que compila dados para a média da década de 1990 em 11 países europeus, mostra que os jovens diplomados, às vezes, tiveram taxas mais altas de desemprego do que os jovens com menos anos de estudo. E na Espanha e na Itália, 1 em cada 4 jovens com educação superior estava desempregado nos anos 1990, sendo de quase $12 \%$ a média de desemprego de nível superior nesses países.

Desemprego juvenil de nível superior significa, quase sempre, dificuldade de se encontrar o primeiro emprego depois de deixar a universidade, em países nos quais as taxas de acesso à educação superior na idade apropriada (18 a 24 anos) ultrapassou os 50\% já em meados dos anos $1980^{29}$. Este fato (dificuldade de se encontrar o primeiro emprego, tendo-se deixado a universidade) significou, para uma parcela expressiva dos jovens de alguns países, o rompimento de uma promessa importante do "capitalismo organizado", e elemento central da solução do "problema das gerações", qual seja, a de que, por meio da educação, as famílias conseguiriam transferir a seus filhos, se não valores ou tra- 
Tabela 1

Taxas de Desemprego dos Jovens de 15 a 29 Anos em Países Selecionados, na Década de 1990, segundo a Escolaridade

\begin{tabular}{l|c|c|c|c}
\hline País & $\begin{array}{c}\text { Educação } \\
\text { Fundamental }\end{array}$ & Ensino Médio & Superior & Total \\
\hline Espanha & 29,4 & 26,9 & 24,5 & 26,9 \\
Finlândia & 43,3 & 23,2 & 11,6 & 26,0 \\
Itália & 20,5 & 21,3 & 24,2 & 22,0 \\
França & 25,6 & 14,8 & 11,5 & 17,3 \\
Irlanda & 28,2 & 14,1 & 9,2 & 17,2 \\
Grécia & 11,8 & 17,3 & 15,4 & 14,8 \\
Suécia & 23,5 & 15,1 & 5,5 & 14,7 \\
Portugal & 8,4 & 10,8 & 8,2 & 9,1 \\
Alemanha & 11,5 & 7,3 & 5,2 & 8,0 \\
Áustria & 8,9 & 5,3 & 5,0 & 6,4 \\
Suíça & 6,4 & 4,4 & 7,9 & 6,2 \\
\hline Média & 19,8 & 14,6 & 11,7 & 15,3 \\
\hline
\end{tabular}

Fonte: Barceinas-Paredes et al. (s.d.p.)

Obs.: Taxa média para períodos variados na década de 1990 (de 1992 a 1999, dependendo do país e da disponibilidade de dados).

dições, ao menos oportunidades de ascensão social, sustentadas por credenciais antes valorizadas pelo mercado de trabalho ${ }^{30}$.

O capitalismo continuou produzindo muita riqueza, mas, nos anos de neoliberalismo, a distribuição da riqueza produzida passou a se dar por mecanismos cada vez menos mediados pelo Estado de Bem-Estar, numa ordem econômica que se tornou mais individualizada, mais precária, mais mercantilizada e muito mais competitiva. Como sugere Vandenberghe (1999), a modernidade tardia trouxe, ademais de individualização, destruição de formas tradicionais de construção de identidade e abertura dos horizontes de possibilidades de identificação dos jovens de todas as classes sociais, estimulando sem dúvida a criatividade social (ver também Domingues, 2002), mas produzindo sempre renovadas fontes de incerteza.

Neste novo ambiente, a incerteza da condição juvenil tornou-se insegurança e vulnerabilidade das condições de vida das novas gerações, que não decorrem apenas da redução de alternativas de escolha profissional ou identitária, embora isso também seja importante. Trata-se, para várias camadas sociais, das mais às menos vulneráveis (e é claro que as 
classes sociais não vivem esse processo da mesma maneira), de efetivo fechamento de vias "virtuosas" de inscrição social, isto é, vias que, uma vez perseguidas, resultem em trajetórias pessoais bem-sucedidas vis-à-vis os projetos e aspirações individuais. Situação que se aprofundou na década seguinte, e se tornou socialmente explosiva depois da crise de 2008.

A crise, que ainda não foi debelada (escrevo em 2014), atualizou as análises catastrofistas dos anos 1990 sobre "o fim dos empregos" ${ }^{\prime 31}$. O desemprego de jovens de 15 a 24 anos chegou à inimaginável cifra de $58 \%$ na Espanha em 2013, marca suplantada apenas pela Grécia (quase $65 \%$ ). Na Zona do Euro, o desemprego juvenil atingiu 23,7\% no mesmo ano, o mais alto em muitas décadas, e mais de um terço era desemprego de longa duração ${ }^{32}$, isto é, um tipo de desemprego que costuma afetar por muito tempo as trajetórias de vida das pessoas ${ }^{33}$. Mais do que nun$\mathrm{ca}$, os jovens passaram a demandar, em lugar de igualdade ou liberdade, como em 1968, emprego para todos, recolocando o trabalho (e a falta dele) no centro do "problema das gerações", e dos mecanismos de construção de projetos de vida, anseios e identidades sociais ${ }^{34}$.

Estas cifras são expressão de uma crise importante e continuada, nos países mais ricos, dos mecanismos de socialização e ordenamento das trajetórias sociais das novas gerações, muito especialmente o sistema escolar e o mercado de trabalho, e o futuro dos jovens de hoje é bem mais inseguro do que o futuro de seus pais ou avós. Tal quadro renovou, uma vez mais, o "problema das gerações". Os "rebeldes sem causa" dos anos 1950 se insurgiram, de maneira individualizada e mesmo heroica, contra a moral hipocritamente puritana de seus pais. Mas no mundo em reconstrução do pós-guerra, não havia desemprego, muito ao contrário, havia carência de mão de obra. Os rebeldes de 1968, por seu lado, se sublevaram, de maneira coletiva e organizada, contra o "mal-estar da civilização" ("seja realista, exija o impossível" foi o lema dos universitários da Sorbonne, inspirado em Marcuse), e realizaram a revolução nos costumes e no mundo do trabalho contra o enrijecimento burocrático da modernidade fordista, também num ambiente de pleno emprego. Os rebeldes de 2008 em diante se insurgiram contra a financeirização desumanizadora do capitalismo, que resultou na drenagem da riqueza social por uma diminuta, mas sempre poderosa, categoria social (rentistas, banqueiros e especuladores em geral), e contra a desestruturação dos mercados de trabalho em toda parte, que produziu taxas sem precedentes de desemprego e o que alguns autores 
estão (de maneira um tanto apressada) denominando "precariado", uma nova, ampla e heterogênea categoria social vulnerável, com empregos estruturalmente precários, insegurança na renda, precariedade das redes sociais de sustentação de suas trajetórias e insegurança quanto ao futuro ${ }^{35}$.

Mais ainda: parte substancial da juventude hoje desempregada foi socializada num período (anos 1980 e 1990) em que a ideologia (neoliberal) dominante sobre as melhores formas de inserção social eram o empreendedorismo, o "faça você mesmo", a empregabilidade (Boltanski e Chiapello, 1999), aspectos da valorizada liberdade de trabalho na "nova economia" informacional e criativa que, como já se disse, estavam na raiz dos movimentos de 1968. O acesso a esse mundo de sonhos, no qual o assalariamento era visto como coisa do passado, seria facultado pelo diploma universitário e a qualificação continuada ao longo da vida. Nada disso está disponível para boa parte dos mais jovens na Europa, como mostram as cifras de desemprego. A crise, nesse sentido, pode ser lida na chave de um conflito geracional, já que os mais velhos estão empregados (a taxa de desemprego de adultos de 30 anos ou mais com nível universitário é próxima de $2 \%$ na Europa, segundo a mesma fonte das cifras apresentadas antes), e o sistema econômico que eles criaram parece satisfazer seus interesses em detrimento da emancipação dos mais jovens.

\section{0 "PROBLEMA DAS GERAÇÕES" NO BRASIL}

Esse quadro de referência, forçosamente superficial, permite pôr em relevo algumas especificidades da situação brasileira. O Brasil é um país de história de migração campo/cidade muito intensa e recente, o que quer dizer que a modernidade urbana e industrial, que fascinou Mannheim e Eisenstadt e era a matriz de sua formulação do problema geracional $^{36}$, também é recente. Em 1950, apenas 36\% dos brasileiros viviam nas cidades. Nos dez anos seguintes deixaram o campo o equivalente a $24 \%$ da população rural contada no início. Isto é, 1 em cada 4 moradores do campo procurou as cidades, totalizando perto de $8 \mathrm{mi}-$ lhões de migrantes. Nos anos 1960 saíram 36\% dos rurícolas existentes no início (mais de 1 em cada 3 pessoas), num total de 13,4 milhões de pessoas; e ao longo da década seguinte, nada menos que $42 \%$ da população rural contada em 1970, ou mais de 17 milhões de brasileiros deixaram o campo ${ }^{37}$. Em 30 anos, pois, as cidades receberam quase $40 \mathrm{mi}-$ lhões de pessoas. Em consequência, em 1980 70\% da população já 
estavam vivendo nos centros urbanos que, contudo, não geraram infraestrutura suficiente para alojar os migrantes, garantir sua saúde e, muito especialmente, educar seus filhos.

Para que se tenha uma ideia dos montantes, em 1960, a taxa de frequência no ensino fundamental da população de referência ( 7 a 12 anos) era de apenas $47 \%$ no Brasil, equivalente à encontrada na Índia e na Turquia. No Uruguai a cifra era bem mais alta, de $87 \%$, chegando a $90 \%$ na Argentina e $98 \%$ no Paraguai e na maioria dos países da Europa, além da África do Sul (Morrisson e Murtin, 2009) ${ }^{38}$. Segundo o Censo de 1960, não chegava a $0,7 \%$ a proporção de brasileiros de 18 a 40 anos com ensino superior completo, e $40 \%$ da população adulta (18 anos ou mais) eram analfabetos. No mundo urbano em gestação, o analfabetismo afligia 1 em cada 4 pessoas ${ }^{39}$.

A urbanização acelerada significou melhoria de vida para parte significativa da população que abandonou o campo em fuga da pobreza, das secas, dos movimentos de concentração fundiária ou qualquer outra razão. Mas a combinação de políticas salariais restritivas (que mantiveram o salário mínimo quase sempre abaixo das necessidades básicas da população, como mostrado, dentre outros, por Oliveira, 1972, e, mais recentemente, Cardoso, 2010), com oferta abundante de mão de obra pouco qualificada, trazida às cidades pela migração, contribuiu para depreciar a renda de todos. Em consequência, a população vinda do campo estabeleceu-se no mundo urbano em patamares muito baixos de renda, o que limitou suas oportunidades por gerações sucessivas.

Neste processo de mudança estrutural, a educação sempre foi um limite à melhoria das condições de vida. Em primeiro lugar, a escola não era valorizada no campo. As pessoas começavam a trabalhar muito cedo, antes dos 10 anos de idade ajudando na lide agrária (se meninos) ou doméstica (se meninas). Com isso, as taxas de evasão escolar sempre foram muito altas. Como mostrado por Cardoso (2010), 40\% dos jovens brasileiros e $50 \%$ das jovens com 15 anos de idade, e que viviam nas cidades, já não estavam na escola em 1970. Entre os de 16 anos a taxa era de $50 \%$ para eles e de $60 \%$ para elas. Na idade padrão de conclusão do ensino médio (18 anos), quase $70 \%$ dos jovens citadinos já tinham deixado a escola, a maioria deles para trabalhar, no caso dos homens, ou para a inatividade, no caso das mulheres. No campo a taxa de 
evasão era ainda maior, com quase $80 \%$ dos jovens fora da escola aos 15 anos de idade, e taxa de analfabetismo superior a $50 \%$.

Isto significa que os jovens começavam a trabalhar muito cedo. A probabilidade de um jovem de 17 anos, vivendo na cidade, estar trabalhando era de $43 \%$ em 1970, taxa que se elevava a $52 \%$ entre os jovens homens de 18 anos. Entre os habitantes do mundo rural as proporções eram de $80 \%$ e $85 \%$, respectivamente ${ }^{40}$.

No Brasil, pois, o trabalho fazia parte do processo de incorporação das novas gerações ao fluxo da vida coletiva, porque ocorria muito cedo nas biografias. O movimento não foi no sentido de socializar ou educar para o trabalho, mas, antes, de socializar pelo trabalho, educar pelo trabalho. E como o nível escolar era sempre muito baixo, o trabalho era, forçosamente, de má qualidade. Isso era ainda mais grave no mundo rural, onde $40 \%$ das crianças de 10 anos não estudavam, chegando a $70 \%$ no caso dos jovens de 15 anos.

Além disso, apesar do abandono precoce da escola por proporção significativa dos jovens, homens e mulheres igualmente, a obtenção de uma ocupação, se era o destino mais provável dos homens que deixavam a escola, não era o único possível. Cerca de 10\% das crianças de 10 anos estavam fora da escola em 1970, e destes, $90 \%$ não estavam no mercado de trabalho. Entre os adolescentes de 15 anos, um terço dos $40 \%$ que não estudavam tampouco estava no mercado de trabalho. No campo as proporções eram bem menores em termos relativos, mas a taxa de crianças de 10 anos fora da escola e não trabalhando era de $27 \%$ (ou $55 \%$ dos que tinham deixado a escola). Entre os de 15 anos, $11 \%$ não estudavam nem trabalhavam ${ }^{41}$.

Por fim, e talvez o mais importante, ainda que os jovens homens já se tivessem majoritariamente inserido no mercado de trabalho ali pelos 22 anos de idade ( $83 \%$ na cidade e $94 \%$ no campo em 1970), esta inserção não se deu em condições tipicamente fordistas de trabalho. $\mathrm{O}$ assalariamento urbano nunca foi universal no Brasil ${ }^{42}$. Em 1940, 36,4\% dos ocupados em atividades não agrícolas eram trabalhadores por conta própria (Prandi, 1978:63). Em 1970 os trabalhadores por conta própria eram $20 \%$ dos ocupados nas cidades (idem). Somem-se a isso os assalariados sem carteira e teremos pelo menos metade da população total empregada em ocupações não reguladas pela institucionalidade herdada do período Vargas, representada pelo assalariamento com cartei- 
ra e os direitos sociais relacionados com ele $e^{43}$. Junto à população jovem a taxa de não regulação era superior a isso.

Esses processos apresentavam grande inércia estrutural. Os censos sucessivos de 1970, 1980 e 1991 registraram poucas mudanças nesse padrão de incorporação das novas gerações, com leve aumento da proporção de jovens estudando e trabalhando a cada decênio, e com redução da proporção daqueles que não estavam nem na força de trabalho nem na escola. Mas em 1991, 89\% dos jovens urbanos de 10 anos de idade estudavam, mesma proporção encontrada em 1970, e a cada decênio, 17 anos configuravam uma fronteira etária que, cruzada, lançava fora da escola pelo menos metade dos jovens urbanos brasileiros do sexo masculino. Para os jovens rurais a fronteira da expulsão da maioria era os 13 anos. Isso só mudaria ao longo dos anos 1990. Claramente, o sistema educacional demorou décadas para se adequar ao aumento da demanda provocado pela intensa migração campo/cidade.

Mudança sensível nesse padrão de inserção social dos jovens só ocorreria nos anos 1990, como mostra o Gráfico 1. Em termos muito gerais, essa mudança resultou no rompimento da simetria da relação entre os dois destinos típicos: sair da escola deixou de significar arrumar um emprego. Primeiro, porque, para proporção crescente dos jovens, escola e trabalho deixaram de ser alternativas excludentes. Uma proporção cada vez maior deles passou a estudar e trabalhar, e isso tanto no campo quanto na cidade ( $20 \%$ dos jovens de 16 anos na cidade, $30 \%$ no campo, $22 \%$ e $24 \%$ dos de 18 anos), o que contribuiu para que retardassem a saída da escola. Quase $88 \%$ dos jovens urbanos de 15 anos estavam na

\section{Gráfico 1}

Relação Escola/Trabalho na Inserção Social de Jovens do Sexo Masculino Nascidos Urbano entre 1978 e 1990, Situação em 2000
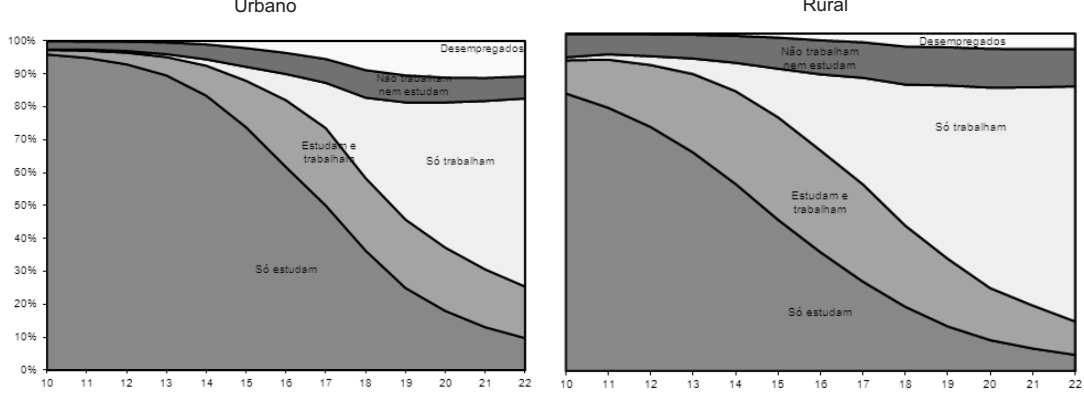

Fonte: Microdados do Censo Demográfico de 2000.

DADOS - Revista de Ciências Sociais, Rio de Janeiro, vol. 58, no 4, 2015 
escola em 2000 (75\% no campo), contra 68\% (e 28\%) em 1980. Em segundo lugar, porque o desemprego (que atingiu $10 \%$ dos jovens de 18 anos em 2000) ganhou relevância como destino provável dos egressos do sistema escolar. Esse fato inaugura um novo cenário na relação escola/ trabalho como mecanismos de inscrição social dos jovens. Agora, ao deixar a escola, os jovens transitam, ou para a força de trabalho, não necessariamente empregada; ou para a inatividade pura e simples. De fato, dos jovens urbanos de 17 anos que haviam deixado a escola para ingressar na força de trabalho ( $26 \%$ do total), metade estava desempregada ou fora da PEA (população economicamente ativa). Entre os de 16 anos, $55 \%$ estavam nessa condição, taxa que chegou a $65 \%$ entre os de 15 anos. Ou seja, quanto mais cedo o jovem urbano deixou a escola em 2000, maior a probabilidade de que seu destino fosse o desemprego ou a inatividade. Em 1980 estes valores eram 21,8\%, 27,5\% e 35,3\%, respectivamente. Muito inferiores, portanto.

Por fim, o Gráfico 2 mostra que pouco mudou no padrão de incorporação social dos jovens na década de 2000 em relação à anterior. Aumentou a proporção de jovens rurais que só estudavam, principalmente entre os mais jovens entre eles; e aumentou muito a proporção dos que não estudavam nem trabalhavam, tanto no campo quanto na cidade, sendo que no campo a situação era bem mais séria. Ainda assim, tal como em 2000, aos 18 anos metade dos jovens brasileiros já estava fora da escola em 2010.

No caso das mulheres, embora elas fossem metade da população em 1970 , eram apenas $21 \%$ da população economicamente ativa $(18 \%$ em

\section{Gráfico 2}

Relação Escola/Trabalho na Inserção Social de Jovens do Sexo Masculino Nascidos entre 1988 e 2000, Situação em 2010

Urbano

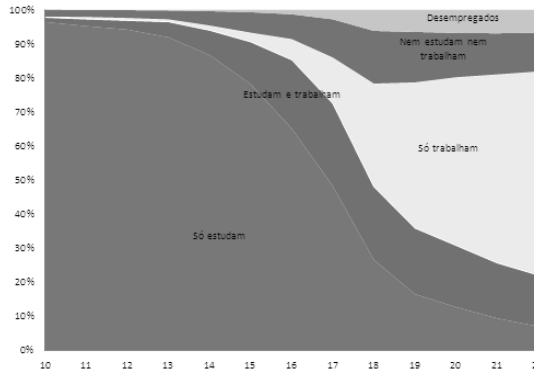

Rural

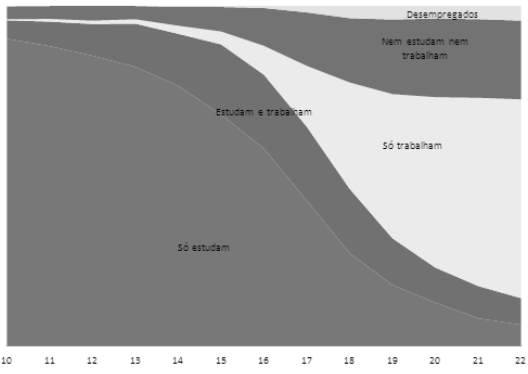

Fonte: Microdados do Censo Demográfico de 2010. 
$1960^{44}$ ). A taxa de atividade das jovens de 22 anos era de 28,5\% em 1970, e $64 \%$ delas não estudavam nem trabalhavam. Mas, segundo a mesma fonte dos gráficos 1 e 2, a taxa de participação na escola por parte das mulheres foi quase sempre menor quando comparada com a dos homens, se somarmos a proporção que estava apenas na escola e a que estava estudando e trabalhando. Isto só mudaria durante os anos 1990, de tal modo que, em 2000, ao menos para quem tinha até 17 anos de idade, a taxa de frequência escolar delas superava a deles, se bem que muito ligeiramente ${ }^{45}$. Contudo, para as mulheres a inércia estrutural geral foi bem menor do que para os homens. Ainda que seja lento o processo de aumento da participação escolar feminina ${ }^{46}$, a proporção das que não trabalhavam nem estudavam caiu bastante a cada década. Tomando-se, por exemplo, as mulheres de 22 anos em 1970, 64\% não trabalhavam nem estudavam, taxa que cairia a 55\% em 1980, $47 \%$ em 1991, até atingir 30\% em 2000. Por fim, também para as mulheres a principal mudança nos anos 1990 foi a emergência do desemprego como fenômeno importante, destino de cerca de $20 \%$ das jovens de 18 anos ou mais naquele ano. A inatividade já não era o destino mais provável, competindo intensamente com a escola, o emprego e o desemprego. E somando-se empregadas e desempregadas, chegava-se a que $61 \%$ das mulheres de 22 anos estavam na força de trabalho em 2000, proporção que atingiu 66\% em 2010, segundo o Censo Demográfico do Instituto Brasileiro de Geografia e Estatística (IBGE).

Ou seja, até 1991, a maioria das mulheres, diferentemente dos homens, ao deixar a escola não buscava uma ocupação. Elas se tornavam inativas em sua maioria. Esta situação era a contrapartida feminina do percurso dos homens, que deixavam a escola para empregar-se de forma precária e insegura. As mudanças estruturais profundas dos anos 1990 mexeram bastante neste quadro, com as mulheres permanecendo por mais tempo na escola e, dentre as que a tinham deixado, uma proporção maior passou a pressionar o mercado de trabalho, com isso reduzindo a taxa de inatividade por comparação com as décadas anteriores, mas aumentando proporcionalmente a taxa de desemprego, sobretudo entre aquelas com 17 e 18 anos. Seja como for, aos 18 anos, $55 \%$ das mulheres citadinas estavam fora da escola em 2000, proporção que caiu um pouco em 2010 (53\%), ainda assim muito alta.

Mais ainda, a variação no interior do país foi sempre muito grande. Em 1970, na Bahia, metade das crianças de 10 anos estava fora da escola, cifra que subia a 55\% no Maranhão, Piauí e Paraíba e $62 \%$ no Acre, contra apenas 7\% no Distrito Federal e em São Paulo. Ainda em 1991 a taxa de 
exclusão escolar dessas crianças variava de $30 \%$ a $40 \%$ no primeiro grupo de estados, contra os mesmos $7 \%$ no segundo.

Dizendo de outro modo: comparando com a experiência europeia brevemente discutida antes, e como mostrado em Cardoso (2010), nós também tivemos nosso capitalismo organizado, nosso Estado de Bem-Estar, nossas políticas públicas de redução das desigualdades de oportunidades. Constituiu-se, aqui como alhures, um mercado de trabalho regulado pelo Estado, e as gerações sucessivas também viveram, em termos médios, melhor do que seus pais, ao menos a partir da década de 1930, quando se intensificou o ritmo de migração dos campos para as cidades. O país viu seu PIB ser multiplicado por 15 entre 1940 e 1980, e o PIB per capita multiplicar-se por 5 . Nossos jovens, malgrado a penúria da condição real da maioria, podiam olhar para o futuro e imaginá-lo melhor do que sua vida presente ${ }^{47}$. As pesquisas de opinião sempre o comprovaram: os brasileiros, desde que se tem notícia de pesquisas deste tipo, sempre acreditaram que estariam melhor amanhã do que estão hoje ${ }^{48}$.

Mas a média, num país muito desigual como o Brasil, mais esconde do que revela os processos sociais subjacentes. Aspecto distintivo de nossa experiência de modernização capitalista é o fato de que nenhum dos mecanismos de ajustamento à ordem burguesa em construção se universalizou, com exceção parcial do acesso ao ensino fundamental, cuja universalização, é bom salientar, ocorreu apenas em fins da década de 1990 (Costa Ribeiro, 2009). Desde 1950 até pelo menos meados da década de 2000 a renda individual de $75 \%$ dos brasileiros foi igual ou menor do que $\mathrm{R} \$ 1.000$ (Santos, 2006). O mercado formal de trabalho, regulado pelo Estado, nunca acolheu mais do que $60 \%$ dos trabalhadores, tendo caído a 40\% no fim dos anos 1990, mesma proporção encontrada em 1940, início do processo de efetivação da "cidadania regulada" (Santos, 1979). Ainda em 2012, apesar da grande formalização ocorrida no mercado de trabalho depois de 2003, a taxa de formalidade era a mesma de 1980 (Cardoso, 2013). Além disso, os empregos sempre foram muito instáveis. Perto de metade da população perde o emprego todos os anos no Brasil, e mais de 30\% têm vários empregos por ano, ou emprego nenhum. Entre os jovens as taxas sempre foram muito mais altas do que isso (dados em Cardoso, 2010).

Também contrariamente à experiência europeia, a posse de um diploma universitário nos anos 1980 e 1990 ainda credenciava os jovens às melhores posições na estrutura ocupacional. A “inflação de creden- 
ciais" entre nós só mostraria sua face nos anos 2000, muito em razão da avalanche de diplomas oriundos do ensino privado de má qualidade. Por aqui, o ensino superior vem se democratizando pelo mercado, e o acesso das camadas inferiores à universidade gerou outras dimensões nas desigualdades de oportunidades. O ensino superior privado é não apenas, na média, de má qualidade, como é também muito concentrado em algumas poucas carreiras, o que piora as chances de sucesso dos recém-formados ${ }^{49}$. A "inflação de diplomas", pois, afeta sobretudo os mais pobres dentre os diplomados.

Ainda assim, a "democratização" ainda é muito restrita. Em 2012, segundo dados da Pesquisa Nacional por Amostra de Domicílios (PNAD), apenas 34\% dos jovens de 18 a 22 estavam estudando, e destes, não mais que $32 \%$ estavam na universidade. Metade ainda cursava o ensino médio. Daqueles com 22 a 25 anos, apenas $23 \%$ estavam cursando ou haviam terminado a universidade, mais de $70 \%$ deles em escolas privadas ${ }^{50}$, valores, como vimos, equivalentes ao que a França atingira nos anos 1970, e os Estados Unidos, no início dos anos 1960.

A avalanche populacional pós-década de 1940, que produziu nossos espaços urbanos segregados, excludentes e desiguais, fruto da diminuta capacidade de o Estado (em seus diversos níveis federativos) responder às carências da maioria ${ }^{51}$, resultou, para as camadas mais pobres, em processos eminentemente privados de incorporação das novas gerações à dinâmica social. Entre os mais pobres, o "problema das gerações" foi equacionado, primeiro, pelas famílias e suas redes sociais e comunitárias, e depois, pelo mercado de trabalho e seus empregos precários, com o Estado participando marginalmente, e por um período muito curto, do ordenamento das trajetórias de vida, por meio de um sistema escolar que só universalizou a escolaridade fundamental ( $8 \mathrm{ou}$ 9 anos, segundo o sistema escolar) no final da década de 1990, como já se disse ${ }^{52}$.

Aquelas redes sociais e comunitárias, é bom marcar, foram constituídas nas cidades de destino dos migrantes, num processo de adaptação/negação/ressignificação das trajetórias pretéritas que não tem nada da ideia de "transmissão das tradições culturais herdadas do passado", cara aos autores discutidos antes. A migração intensa e recente significou, em grande medida, a diluição dos horizontes de expectativas de todos, pais e filhos, num projeto geral, mas difuso, de "melhoria de vida" na cidade. A vida de todos, migrantes e filhos, se voltou, de um 
modo ou de outro, para o futuro, cuja construção se deu, porém, em condições muito precárias de vida no presente, o que dificultou ou mesmo impediu que parte considerável das famílias realizasse o sonho, sempre adiado, de escolarização de seus membros.

Mesmo as famílias das classes médias e altas seguiram vias privadas de socialização de seus filhos, já que, no passo em que a pressão populacional aviltou a qualidade do ensino público, a maior parte daquelas transferiu os filhos para escolas privadas, cuja maior qualidade diferencial passou a ser condição para o acesso, via vestibular, ao ensino superior público. Assim, segundo o Censo Demográfico de 2010, nas famílias com renda per capita entre os 10\% mais ricos, $77 \%$ dos que frequentavam o ensino fundamental estavam numa escola particular ${ }^{53}$. No ensino médio, $66 \%$ estavam nessa condição. Nas famílias entre as $40 \%$ mais pobres, as proporções eram inferiores a $5 \%$ nos dois níveis escolares. Em cidades com 500 mil habitantes ou mais a taxa foi ainda mais alta, de $85 \%$ (ensino fundamental) e $72 \%$ (médio) dos filhos das famílias entre as $10 \%$ mais ricas estavam em escolas privadas, contra apenas $10 \%$ ou menos entre as $40 \%$ mais pobres.

Isso aprofundou as clivagens já existentes na situação geracional ${ }^{54}$, já que aqueles jovens condenados ao ensino público fundamental de má qualidade quase nunca acederiam ao ensino superior público, ou mesmo a qualquer ensino superior. Ainda segundo o Censo de 2010, nas famílias com renda per capita entre os $40 \%$ mais pobres, apenas 1 em cada 5 jovens de 19 a 25 anos estava estudando, enquanto nas 10\% mais ricas, 1 em cada 2 frequentava escola. A desigualdade de oportunidades, num mundo privatizado e cheio de filtros e gargalos no acesso às posições superiores (como o vestibular, os concursos para cargos públicos, o preconceito racial, a discriminação de gênero etc.) tende a perpetuar as clivagens e hierarquias sociais, ao estruturar de maneira também desigual e hierárquica as chances de vida das novas gerações.

Se o peso da socialização das novas gerações esteve quase sempre nos ombros das famílias, mesmo estas eram (e são) arranjos muito instáveis e vulneráveis (ver Zaluar, 2014), principalmente entre os mais pobres, que sempre foram a maioria da população. Em 1970, por exemplo, tomando-se apenas o antigo Estado da Guanabara (hoje cidade do Rio de Janeiro), perto de $58 \%$ das famílias viviam com até 1 salário mínimo por mês de renda per capita ${ }^{55}$. Porém, $25 \%$ do total de famílias eram chefiados por mulheres, quase todas sem cônjuge, e a renda per capita de $65 \%$ delas era igual ou inferior a 1 salário mínimo. Mais da 
metade eram mulheres com filhos ${ }^{56}$. O fenômeno de mulheres pobres criando sozinhas seus filhos não é novo no Brasil (Costa Ribeiro, 2009), e sempre foi um dos principais responsáveis pela transmissão intergeracional das desigualdades. E estamos falando de um dos municípios mais ricos do país. Ainda em 2010, e malgrado todo o apressado alarde em torno do crescimento da "nova classe média" (Neri, 2010), 48\% (ou quase metade) dos brasileiros viviam em domicílios cuja renda familiar per capita estava entre os $40 \%$ mais pobres, isto é, era igual ou inferior a $\mathrm{R} \$ 450$ por pessoa ${ }^{57}$, em valores atualizados (de janeiro de 2014).

O Estado vem penetrando muito lentamente os mecanismos de socialização das novas gerações, e ainda hoje não se pode dizer que se tenha rompido o padrão privatizado que sempre os caracterizou. A Constituição de 1988 instituiu, por exemplo, os conselhos tutelares da criança e do adolescente, e desde então vêm se delineando outras políticas públicas relevantes voltadas para estas dimensões, como o bolsa-escola nos anos 1990, de baixa cobertura, e, atualmente, o bolsa-família, além da política de valorização do salário mínimo ${ }^{58}$. São também importantes o combate ao trabalho infantil e o aumento gradativo da idade mínima de entrada no mercado de trabalho, hoje em 16 anos, ao menos na lei ${ }^{59}$. Conquanto importantes como mecanismos de redução da estrutural vulnerabilidade das novas gerações nascidas em famílias mais pobres, os programas de transferência de renda não melhoram a qualidade da educação ou da saúde pública, que exige investimentos de outro tipo, e muito mais vultuosos, embora se invista mais nesses setores, hoje, do que jamais se investiu no Brasil (Cardoso, 2013: Introdução).

Entre nós, pois, o "problema das gerações" adquiriu um rosto próprio, muito diverso do padrão europeu esboçado nas primeiras seções deste texto. Por décadas as novas gerações foram acolhidas num fluxo populacional que era isso mesmo, população em fluxo, movendo-se do campo para a cidade e nela reconstruindo padrões de sociabilidade, reinventando tradições culturais e lutando por meios de vida em condições muito vulneráveis, o que fez do trabalho precoce dos jovens um mecanismo central de sua socialização. Num sentido muito profundo, a experiência das gerações sucessivas foi de efetiva construção social de sua realidade, já que as cidades foram inteiramente transformadas pela avalanche populacional, e seus mercados de trabalho e suas instituições públicas nunca foram suficientes para incorporar produtivamente todos os migrantes, com o que boa parte deles precisou criar meios de vida por conta própria e por fora daquelas instituições ${ }^{60}$. O abandono precoce da escola reduziu o tempo de exposição de boa parte dos jo- 
vens à institucionalidade pública e aos mecanismos públicos de transmissão da "herança cultural", transferindo aos próprios jovens, e de novo muito cedo em suas trajetórias de vida, o ônus de unificar a experiência do mundo em identidades individuais e coletivas. Estas foram forjadas, sobretudo entre os mais pobres, maioria da população, na negociação privada de experiências com outros jovens e com o mundo dos adultos, materializado nos recursos sociais e econômicos cujo acesso esteve sempre desigualmente distribuído, em privilégio das camadas mais ricas da população. Estas, por seu lado, nas grandes cidades mais do que no resto do país, foram aos poucos construindo um mundo próprio, higienicamente distante da maioria, fechado em condomínios seguros, escolas privadas, shopping centers, mundo também privado ${ }^{61}$, porém em nada semelhante ao ambiente vulnerável e turbulento que acolheu as gerações mais pobres.

Nesse sentido, "o problema das gerações", no Brasil, deve ser conjugado no plural. A experiência geracional foi sempre muito desigual e hierárquica, e as diferentes classes sociais experimentaram à sua maneira os processos de privatização da socialização, e construíram à sua maneira a sucessão geracional, maneiras, muitas vezes, incomensuráveis e irredutíveis umas às outras. Houve, e há, obviamente, inúmeros pontos de contato entre essas maneiras. Nem todas as famílias mais ricas mantêm seus filhos em escolas privadas, e uma parcela dos mais pobres consegue ser educada nelas. Parte dos mais pobres consegue acesso ao ensino superior público de qualidade, assim como parte dos mais ricos paga por escolas ruins. $\mathrm{O}$ ambiente cultural das grandes cidades oferece inúmeras oportunidades para o compartilhamento da experiência geracional, assim também o mundo da participação política e, mais recentemente, as redes sociais virtuais. E mesmo que vivam, no processo de socialização, trajetórias divergentes, proporções não desprezíveis destas frações geracionais se encontrarão no mundo do trabalho e compartilharão, por exemplo, o destino de sua empresa, mesmo que estando em posições hierárquicas muito distintas. Tarefa sempre atual de pesquisa é, justamente, desvendar os mecanismos pelos quais experiências geracionais tão díspares no ponto de partida, porque clivadas por grandes desigualdades de classe e de oportunidades de vida, resultam nesse amálgama turbulento e em instável equilíbrio que é a sociedade brasileira.

(Recebido para publicação em maio de 2014)

(Reapresentado em setembro de 2014) (Aprovado para publicação em março de 2015) 


\section{NOTAS}

1. Utilizo uma tradução para o espanhol da versão original do texto em alemão, que traz a numeração de páginas do original. Nas citações utilizo esta numeração. A tradução foi publicada em http:/ / www.reis.cis.es/REIS/PDF/REIS_062_12.pdf, acessada em novembro de 2013. Com exceção da epígrafe, no resto do texto verti o espanhol para o português.

2. “A geração", sustentou Ortega y Gasset (1966[1923]:147), "compromisso histórico entre massa e indivíduo, é o conceito mais importante da história, e, por assim dizer, a dobradiça [gozne] sobre a qual esta executa seus movimentos".

3. O problema já havia atraído a atenção de autores também interessados na dinâmica cultural das sociedades modernas, dentre eles o já citado Ortega y Gasset (1923), que Mannheim arrola na bibliografia de seu texto, mas não cita diretamente, e Pinder (1926), que inspirou mais de perto a formulação mannheimiana, como veremos. Mannheim arrola ainda as abordagens anteriores de Dilthey, Heidegger, Comte e outros, numa rigorosa reconstrução do "estado do problema" (termos dele) na pesquisa social e na filosofia desde o século XIX.

4. Sobre a juventude hitlerista, ver o clássico de Koch (1975). Para um balanço das pesquisas sobre a Juventude Fascista italiana, Ostenc (1986).

5. Sobre os antecedentes e o entorno das conferências "A política como vocação" e "A ciência como vocação", de Weber, ver Schluchter (2011: cap. 1).

6. É claro que entre o Weber de 1917-1919 e o Mannheim de 1943 houve o holocausto e a Segunda Guerra Mundial, mas houve também a humilhação da Alemanha pelo tratado de Versalhes, repudiado com veemência por Weber. É provável que ele condenasse o nazismo por tudo o mais, mas não por tentar resgatar a honra do país.

7. O livro teve reedição em 2002 (e novamente em 2009), tendo sido revisto e ampliado, incluindo uma nova introdução e capítulos adicionais sobre os movimentos estudantis de 1968.

8. O tema está mais bem desenvolvido em Mannheim (1961). Ver, sobre isso, Groppo (2009) e Peregrino (2011).

9. Algumas dessas funções das instituições foram sintetizadas por Douglas (1979).

10. Devo a Wanderley Guilherme dos Santos a lembrança de Todos os Homens são Mortais, grande romance da mesma Beauvoir, publicado em Paris em 1946 e com edição brasileira de 1959. O personagem central é um rei do século XIII que se torna imortal após tomar um elixir, e conta sua história a uma personagem que, no século XX, sonha com a imortalidade. Para o imortal, tudo muda, mas tudo parece enfadonhamente o mesmo, como bem antecipou Mannheim em 1928.

11. O fordismo como arranjo societal global teve sua teorização mais sólida formulada pela Escola Francesa da Regulação, a partir do livro divisor de águas de Aglietta (1974). Curioso que o livro tenha sido publicado no momento em que esse mesmo arranjo entrava em crise profunda.

12. Como mostraram, dentre muitos outros, Bourdieu e Passeron (1964 e 1974).

13. O regramento era tal que era possível falar-se, em termos idealtípicos, em um "padrão fordista de transição da escola para o trabalho" (Cardoso, 2010), caracterizado por controles estatais sobre a construção de qualificações no sistema educacional e 


\section{Adalberto Cardoso}

coordenação pública dos mecanismos de entrada no mercado de trabalho; e de um "curso de vida fordista" no mercado de trabalho, caracterizado por crescentes níveis de consumo (para operários e classes médias), ascensão social via mobilidade ocupacional, e por segurança no emprego e na renda, antes cativos de servidores públicos (Myles, 1990).

14. Em 1986, Hans-Peter Blossfeld publicou importante artigo comparando três gerações de alemães, nascidas em 1929-1931, 1939-1941 e 1949-1951, e mostrou que cada nova geração atingiu posições mais altas de prestígio na escala ocupacional do que a anterior, e o fez mais rapidamente, isto é, mais cedo em suas trajetórias empregatícias.

15. O clássico sobre o tema é sem dúvida Bell (1960), um dos primeiros a chamar a atenção para a mudança na estrutura de classes no capitalismo avançado, com o enxugamento do operariado industrial e o crescimento vertiginoso do emprego nos serviços. O tema seria retomado nos anos 1970 por vários autores, o mais polêmico deles sendo, talvez, Claus Offe (1985), com sua hipótese da "perda da centralidade do trabalho" na teoria social e na prática política.

16. Ver a coletânea também clássica de Croach e Pizzorno (1978).

17. A referência, obviamente, eram os movimentos juvenis patrocinados pelos adultos, como as várias juventudes totalitárias europeias, o escotismo, as fraternidades estudantis etc.

18. Mas Boltanski e Chiapello (1999) mostraram que este mesmo capitalismo tem grande capacidade de incorporar a crítica que o antagoniza, fazendo dela uma força produtiva. A "revolução" gerencial dos anos 1980 levou para dentro das fábricas e das empresas em geral os ideais de autonomia, criatividade, flexibilidade, realização pessoal no trabalho, e também a crítica da divisão fordista do trabalho que estavam na raiz dos movimentos de 1968. A nova ideologia do mundo do trabalho era uma decupagem fiel do que queriam os operários e estudantes no ocaso dos "trinta gloriosos", isto é, no ocaso do "círculo virtuoso do fordismo" (Boyer, 1990), que assegurara a prosperidade sempre crescente do capitalismo ocidental no pós-guerra, mas que gerara insatisfação social também crescente, desencadeando a revolta.

19. Ver, também, van Zanten (2001) e Duru-Bellat e van Zanten (2012).

20. As coisas se passaram de modo muito diverso no Brasil, como veremos.

21. É conhecida a pichação parisiense de 1968, Deus está morto, Freud está morto, Marx está morto, e eu não me sinto muito bem. E também a libertária Seja realista, exija o impossível.

22. É preciso fazer justiça a Mannheim, que já em 1928 escreveu que a socialização é uma relação, uma interação em que os pais também aprendem com os filhos, assim como os professores aprendem com os alunos.

23. Não há espaço para discutir o tema, mas Beck (2010, cujo original é de 1986) já propusera a ideia da socialização individualizante à aberta na modernidade tardia, fruto da crise da sociedade industrial. Uma crítica radical a qualquer noção de "socialização" como inculcação ou incorporação de hábitos e valores é Archer (2007).

24. Utilizo "sociedade" entre aspas porque o ambiente onde nascemos é um conjunto complexo de entes (pessoas, instituições, patrimônio materializado no território, orientações culturais, códigos de conduta, natureza...) que, no ciclo de vida, convocarão nossa atenção, nossa amizade, nosso amor, nossa lealdade, nossa participação, nosso entendimento, nossa criatividade, nossos múltiplos engajamentos, e nada disso é convocado "pela sociedade", como se ela fosse um ente unitário. Quem estabele- 
ce a unidade do mundo externo é o indivíduo, e a unidade só existe nele, na forma de sua identidade.

25. Séries históricas completas de emprego e desemprego desde 1970, para os países da Organização para a Cooperação e Desenvolvimento Econômico (OCDE), estão disponíveis em http://www.bls.gov/fls/flscomparelf/lfcompendium.xls. Acessado em janeiro de 2014.

26. Por exemplo, Trow (1973). Os dados seriam revistos e atualizados por Kerr (1991).

27. Em 1991, utilizando dados do final dos anos 1970, Mincer (1991) mostrou que jovens com diploma universitário tinham taxas menores de desemprego do que os demais, e ficavam menos tempo desempregados, quando perdiam o emprego.

28. Trabalho pioneiro sobre a desvalorização dos diplomas universitários no Brasil é Prandi (1982).

29. Boa parte desses jovens comporá, mais tarde, as estatísticas dos "nem nem", isto é, jovens que não estudam, não trabalham e não procuram emprego.

30. Bourdieu (1979) foi um dos muitos a chamar a atenção para a mudança no padrão de transmissão intergeracional dos capitais, decorrente da massificação do ensino superior a partir dos anos 1960. Mesmo as classes mais altas passaram a depender cada vez mais da educação de seus filhos como garantia de reprodução das posições superiores.

31. Ver Bridges (1995) e Rifkin (1996) para visões radicais.

32. Dados disponíveis em http://www.ippr.org/images/media/files/publication/ 2013/11/states-of-uncertainty_Nov2013_11453.pdf. Acessado em janeiro de 2014.

33. Ver Hammer (2004) e Blossfeld et al. (2005).

34. Nesse ambiente, o principal movimento social na Espanha pós-crise se autodenominou "los indignados". Indignação, desespero e desesperança se conjugam na mesma palavra, e tornou-se comum o termo "geração perdida" para se referir aos jovens espanhóis, gregos ou portugueses que não estavam trabalhando, mas já tinham completado o ciclo escolar. Sobre os "indignados", ver Rosenmann (2012).

35. A literatura sobre isso está aumentando. Standing (2011) é o expoente internacional, mas no Brasil há adeptos aguerridos, que disputam o significado empírico e teórico do termo: Braga (2012) e Alves (2013).

36. Para Eisenstadt (2002), grupos etários e movimentos juvenis tendem a surgir apenas em sociedades cujo mecanismo integrador não é mais a família ou as linhagens de parentesco, mas a divisão do trabalho.

37. As proporções estão em Merrick (1986:62). Os valores absolutos foram calculados por mim, com base nos dados censitários do início de cada década, disponíveis nas séries históricas do IBGE.

38. As cifras são arredondamentos a partir da série de gráficos apresentados pelos autores no anexo da publicação.

39. Dados tabulados para este estudo a partir dos microdados do Censo Demográfico de 1960.

40. Esses dados são analisados longamente por Cardoso (2010).

41. Os dados são fruto de tabulação dos microdados dos Censos Demográficos. 


\section{Adalberto Cardoso}

42. Na França, no auge da "sociedade salarial", perto de $90 \%$ da população se inseriam como assalariados no mercado de trabalho (Castel, 1998). Alemanha, Inglaterra, Estados Unidos e Japão são casos semelhantes.

43. Lembre-se que, até a universalização do atendimento à saúde pela Constituição de 1988, o acesso à saúde pública era privilégio dos assalariados com carteira e funcionários públicos.

44. Dados em Costa Ribeiro (2007: 311). Essa proporção era equivalente à encontrada em Portugal e Espanha, os países mais pobres da Europa no mesmo ano. Ver Crouch (1999:430-431).

45. A dos homens volta a ultrapassar a das mulheres aos 18 anos de idade.

46. Tomando-se as jovens de 16 anos, por exemplo, 40\% delas estudavam em 1970 (somando-se as que também trabalhavam). Em 1980 a proporção era de 46\%, em 1991 $58 \%$ e, em 2000, 67,4\%. Entre os homens as taxas foram, respectivamente: $44 \%, 49 \%$, $52,5 \%$ e $66,2 \%$.

47. Sobre as mudanças estruturais nos últimos 60 anos, ver Cardoso (2010).

48. A literatura sobre migrações também está pejada de referências ao desejo de "melhorar de vida" por trás da decisão de migrar. Ver Durham (1973) e Perlmann (1977).

49. Em 2013, por exemplo, mais de 35\% das matrículas no ensino superior privado foram em direito, administração e contabilidade, contra $17 \%$ das matrículas no ensino público, segundo o Instituto Nacional de Estudos e Pesquisas Educacionais (Inep).

50. Dados tabulados a partir da base da PNAD para este trabalho.

51. Ver, dentre outros, Ribeiro (1997) e Caldeira (2000).

52. Mesmo o serviço militar obrigatório ("escola de civismo", como queria Olavo Bilac) incide por período curto na trajetória de vida de parcela reduzida dos jovens homens (há sempre excesso de contingente nos alistamentos anuais). E embora o alistamento seja obrigatório para todo homem no ano em que completa 18 anos, está por ser contada a história do papel real das forças armadas na socialização dos jovens no Brasil. Algumas exceções sobre os últimos anos são Kulhmann (2001), Castro e Chinelli (2006) e Lima (2010). Uma excepcional reconstrução histórica cobrindo a segunda metade do século XIX e a primeira do XX é Beattie (2001).

53. Dados tabulados para este trabalho a partir dos microdados do Censo de 2010.

54. Na conceituação de Mannheim (1928:529), a situação geracional é a "comunidade de pertencimento a anos de nascimento próximos", sendo, portanto, uma condição contingente na qual a pessoa está situada (independentemente se saber disso) simplesmente por ter nascido no mesmo período que outras da mesma geração.

55. O salário mínimo valia, em 1970 , em torno de $\mathrm{R} \$ 540,00$ em valores de outubro de 2013 (deflacionado pelo Índice Nacional de Preços ao Consumidor Amplo - IPCA). A série histórica completa do salário mínimo, em valores atualizados, pode ser encontrada em www.ipeadata.gov.br.

56. Microdados do Censo Demográfico de 1970 tabulados para este estudo.

57. Microdados do Censo Demográfico de 2010 tabulados para este estudo. Valores atualizados pelo IPCA. Note-se que Marcelo Neri não considera a renda familiar per capita, apenas a renda familiar total para afirmar que mais da metade dos brasileiros estão na classe média. Mas é a renda familiar per capita que mede adequadamente a capacidade de consumo e o bem-estar material das famílias, não a renda total. 
58. Avaliações desses programas podem ser encontradas em Frota (2004); Sposito e Corrochano (2006) e Soares et al. (2006).

59. A agenda do "trabalho decente" no Brasil foi escrutinada, dentre outros, por Abramo et al. (2013).

60. Dentre os muitos que escreveram sobre a crise urbana no Brasil resultante dos processos apenas pincelados aqui, destacam-se Kowarick (1979) e Cano (2011).

61. Clássico sobre o tema é Caldeira (2000), sobre a Região Metropolitana de São Paulo. 


\section{Adalberto Cardoso}

\section{REFERÊNCIAS BIBLIOGRÁFICAS}

ABRAMO, Laís; ARAÚJO, Andrea; BOLZON, André. (2013), “Tripartismo e Participação Social: Potencialidades e Desafios do Encontro entre Dois Processos na I Conferência Nacional de Emprego e Trabalho Decente". Revista Latino-Americana de Estudos do Trabalho, Ano 18, vol. 30, pp. 211-248.

AGLIETTA, Michel. (1974), Accumulation et Régulation du Capitalisme en Longue Période. Exemple des États-Unis (1870-1970). Paris, Maspéro.

ALVES, Giovanni. (2013), Dimensões da Precarização do Trabalho: Ensaios de Sociologia do Trabalho. Bauru, Projeto Editorial Praxis.

ARCHER, Margaret. (2007), Making our Way through the World. Cambridge, Cambridge University Press.

BARCEINAS-PAREDES, Fernando et al. (s.d.p.), Unemployment and Returns to Education in Europe. Working Paper (mimeo). Disponível em http:/ / www.etla.fi /PURE/ Retunemp.pdf. Acessado em janeiro de 2014.

BEATTIE, Peter M. (2001), The Tribute of Blood. Army, Honor, Race and Nation in Brazil: 1864-1945. Duke, Duke University Press.

BECK, Ulrich. (2010), Sociedade de Risco. Rumo a uma Outra Modernidade. São Paulo, Editora 34.

BELL, Daniel. (1960), The End of Ideology. Cambridge, Cambridge University Press.

BLOSSFELD, Hans-Peter. (1986), “Career Opportunities in the Federal Republic of Germany: A Dynamic Approach to the Study of Life-course, Cohort and Period Effects". European Sociological Review, vol. 2, no 3, pp. 208-225.

et al. (eds.). (2005), Globalization, Uncertainty and Youth in Society. London, Routledge.

BOLTANSKI, Luc; CHIAPELLO, Eve. (1999), Le Nouvel Esprit du Capitalisme. Paris, Gallimard.

BOURDIEU, Pierre. (1979), La Distinction. Paris, Minuit.

; PASSERON, Jean-Claude. (1964), Les Héritiers. Les Étudiants e la Culture. Paris, Minuit.

. (1974), A Reprodução: Elementos para uma Teoria do Sistema de Ensino. Rio de Janeiro, Francisco Alves.

BOYER, Robert. (1990), A Teoria da Regulação: Uma Análise Crítica. São Paulo, Nobel.

(1995), “Capital-labour Relations in OECD Countries: From the Fordist Golden Age to Contrasted National Trajectories", in J. Shor e J.-I. You (eds.), Capital, the State and Labour. A Global Perspective. Aldershot, United Nations University Press, pp. 18-69.

BRAGA, Ruy. (2012), A Política do Precariado: Do Populismo à Hegemonia Lulista. São Paulo, Boitempo.

BRIDGES, William. (1995), Um Mundo sem Empregos. São Paulo, Makron Books.

CALDEIRA, Tereza P. R. (2000), Cidade dos Muros. Crime, Segregação e Cidadania em São Paulo. São Paulo, Edusp/Editora 34. 
CANO, Wilson. (2011), Ensaios sobre a Crise Urbana do Brasil. São Paulo, Editora da Unicamp.

CARDOSO, Adalberto. (2010), A Construção da Sociedade do Trabalho no Brasil. Uma Investigação sobre a Persistência Secular das Desigualdades. Rio de Janeiro, FGV Editora.

(2013), Ensaios de Sociologia do Mercado de Trabalho Brasileiro. Rio de Janeiro, FGV Editora.

CASTEL, Robert. (1998), As Metamorfoses da Questão Social: Uma Crônica do Salário. Petrópolis, RJ, Vozes.

CASTRO, Celso e CHINELLI, Fernanda. (2006), Serviço Militar Obrigatório: O Ponto de Vista dos Recrutas. Trabalho apresentado no 30 Encontro Anual da Anpocs, Caxambu, MG, 24-28 de outubro.

COSTA RIBEIRO, Carlos A. (2009), Desigualdade de Oportunidades no Brasil. Belo Horizonte, Argvmentvm Editora Ltda.

CROUCH, Colin. (1999), Social Change in Western Europe. Oxford, Oxford University Press.

; PIZZORNO, Alessandro (orgs.). (1978), The Resurgence of Class Conflict in Western Europe since 1968. London, The MacMillan Press.

DOMINGUES, José M. (2002), “Gerações, Modernidade e Subjetividade Coletiva”. Tempo Social, vol. 14, no 1, pp. 67-89.

DOUGLAS, Mary. (1979), How Institutions Think. Syracuse, Syracuse University Press.

DUBAR, Claude. (1991), La Socialization. Paris, Armand Colin.

DURHAM, Eunice R. (1973), A Caminho da Cidade: A Vida Rural e a Migração para São Paulo. São Paulo, Perspectiva.

DURU-BELLAT, Marie; VAN ZANTEN, Agnès. (2012), Sociologie de l'École (4a- ed.). Paris, Armand Colin.

EISENSTADT, Shmuel. (2002) [1956], From Generation to Generation (2a ed. ampliada). New York, Transaction Publishers.

(1971), "Contemporary Student Rebellions: Intellectual Rebellion and Generational Conflict". Acta Sociologica, vol. 14, no 3, pp. 169-182.

FROTA, Maria G. (2004), Associativismo Civil e Participação Social. Tese (Doutorado em Sociologia), Instituto de Estudos Sociais e Políticos, Universidade do Estado do Rio de Janeiro (IESP-UERJ), Rio de Janeiro. Disponível em http://www.IESP-UERJ. br/biblioteca/teses/maria\%20guiomar.pdf. Acessado em janeiro de 2010.

GORZ, André (org.). (1973), Critique de la Division du Travail. Paris, Seuil.

GROPPO, Luís A. (2009), “O Funcionalismo e a Tese da Moratória Social na Análise das Rebeldias Juvenis". Estudos de Sociologia, vol. 14, no 26, pp. 37-50.

HAMMER, Torild. (2004), Labour Market Integration of Unemployed Youth in a Life Course Perspective. (mimeo). Disponível em http://www.google.com.br/url?sa= t\&rct=j\&q=\&esrc=s\&source=web\&cd=2\&ved=0CDMQFjAB\&url=http $\% 3 \mathrm{~A} \% 2 \mathrm{~F} \% 2 \mathrm{Fvi}-$ tal.new.voced.edu.au $\% 2$ Fvital $\% 2$ Faccess $\% 2$ Fservices $\% 2$ FDownloa d \% 2 Fng v \% 3 A $6715 \% 2$ FS OURCE2 \& e i = 1 W 7 Y U o P x N O e z s Q T

DADOS - Revista de Ciências Sociais, Rio de Janeiro, vol. 58, nº 4, 2015 


\section{Adalberto Cardoso}

a4YC4BA\&usg=AFQjCNGEAM44Y7R_77VlkAUJbAgHace8Ig\&bvm=bv.59568 121,d.cWc.

KERR, Clark. (1991), The Great Transformation in Higher Education, 1960-1980. Albany, State University of New York.

KOCH, H. Wolfgang. (1975), The Hitler Youth. Origins and Development: 1922-1945. New York, Barns \& Noble.

KORPI, Walter. (1983), The Democratic Class Struggle. London, Routledge and Kegan Paul.

KOWARICK, Lucio. (1979), A Espoliação Urbana. São Paulo, Paz e Terra.

KULHMANN, Paulo Roberto L. (2001), O Serviço Militar, Democracia e Defesa Nacional: Razões de Permanência do Modelo de Recrutamento no Brasil. Dissertação (Mestrado em Ciência Política), Faculdade de Filosofia, Letras e Ciências Humanas da Universidade de São Paulo, São Paulo.

LARUE, Andrée; MALEFANT, Romaine; JETTE, Mylène. (2009), “L'Indécision Vocationnelle et le Retour aux Études". Savoirs, no 19, pp. 57-74.

LIMA, João Maria de. (2010), Serviço Militar Obrigatório no Brasil: Uma Reflexão Atual das Práticas e Representações Usadas na Construção da Identidade Militar (2000-2008). Dissertação (Mestrado em História), Faculdade de Ciências Humanas da Universidade Federal da Grande Dourados, Dourados.

MANNHEIM, Karl. (1993) [1928], “El Problema de las Generaciones”. Revista Española de Investigaciones Sociológicas, no 62. Disponível em http://www.reis.cis.es/REIS/ PDF/REIS_062_12.PDF.

. (1961) [1952], “O Problema da Juventude na Sociedade Moderna”, in Diagnóstico de nosso Tempo. Rio de Janeiro, Zahar, pp. 36-61.

MARCUSE, Herbert. (1955), Eros and Civilization. Boston, Beacon Press.

. (1964), One-Dimensional Man. Boston, Beacon Press.

(1972), Counter-Revolution and Revolt. Boston, Beacon Press.

MAUGER, Gérard. (2013), “Juventude: Idades da Vida e Gerações”. DADOS - Revista de Ciências Sociais, vol. 56, no 1, pp. 169-183.

MERRICK, Thomas W. (1986), “A População Brasileira a Partir de 1945”, in E. Bacha e H. S. Klein (orgs.), A Transição Incompleta: Brasil desde 1945. Rio de Janeiro, Paz e Terra, vol. 1, pp. 31-72.

MINCER, Jacob. (1991), “Education and Unemployment”. Working Paper No. 3838, Cambridge, NBER Working Paper Series. Disponível em http: / / www.nber.org/papers / w3838.pdf?new_window=1. Acessado em janeiro de 2014.

MIRON, Gary. (1993), Choice and the Use of Market Forces in Schooling: Swedish Education Reforms for the 1990's. Estocolmo, Institute of International Education.

MORRISSON, Christian; MURTIN, Fabrice. (2009), "The Century of Education". CEE DP 109, London School of Economics. Disponível em http:/ / cee.lse.ac.uk/ceedps / ceedp109.pdf. Acessado em abril de 2011. 
MYLES, John. (1990), "States, Labor Markets and Life Cycles", in R. Friedland e A. F. Robertson (eds.), Beyond the Marketplace: Rethinking Economy and Society. New York, Aldine de Gruyter, pp. 271-298.

NERI, Marcelo C. (2010), A Nova Classe Média: O Lado Brilhante dos Pobres (The New Middle Class: The Bright Side of the Poor). Rio de Janeiro, FGV/CPS.

OFFE, Claus. (1985), Disorganized Capitalism. Chicago, MIT Press (editado por John Keane).

OLIVEIRA, Francisco de. (1972), "A Economia Brasileira: Crítica da Razão Dualista". Estudos Cebrap, no 2, pp. 4-82.

ORTEGA Y GASSET, José. (1966) [1923], "El Tema de Nuestro Tiempo", in J. Ortega y Gasset, Obras Completas. (6a ed.). Madri, Revista de Occidente, vol. III.

OSTENC, Michel. (1986), "La Education en Italie Pendant le Fascisme. Bilan et Perspectives de Recherches". Histoire de l'Éducation, vol. 30, pp. 13-27. Disponível em http:// www.persee.fr/web/revues/home/prescript/article/hedu_0221-6280_1986_ num_30_1_1407. Acessado em dezembro de 2013.

PEREGRINO, Mônica. (2011), "Juventude, Trabalho e Escola: Elementos para Análise de uma Posição Social Fecunda". Cadernos Cedes, vol. 31, no 84, pp. 275-291.

PERLMAN, Janice E. (1977), O Mito da Marginalidade: Favelas e Política no Rio de Janeiro. Rio de Janeiro, Paz e Terra (Coleção Estudos Brasileiros, 18).

PINDER, Wilhelm. (1926), Das Problem der Generation in der Kunstgeschichte Europas. Berlim, Verlag.

PRANDI, Reginaldo. (1978), O Trabalhador por Conta Própria sob o Capital. São Paulo, Símbolo.

(1982), Os Favoritos Degradados: Ensino Superior e Profissões de Nível Universitário no Brasil de Hoje. São Paulo, Edições Loyola.

PRZEWORSKI, Adam. (1989), Capitalismo e Social-Democracia. São Paulo, Companhia das Letras.

RIBEIRO, Luiz Cesar de Q. (1997), Dos Cortiços aos Condomínios Fechados. As Formas da Produção da Moradia na Cidade do Rio de Janeiro. Rio de Janeiro, Civilização Brasileira.

RIFKIN, Jeremy. (1996), O Fim dos Empregos. São Paulo, Makron Books.

ROSENMANN, Marcos R. (2012), Los Indignados. El Rescate de la Política. Madri, Akal.

SANTOS, Wanderley G. dos. (1979), Cidadania e Justiça. Rio de Janeiro, Campus.

. (2006), Horizonte do Desejo: Instabilidade, Fracasso Coletivo e Inércia Social. Rio de Janeiro, FGV Editora.

SCHLUCHTER, Wolfgang. (2011), Paradoxos da Modernidade. Cultura e Conduta na Teoria de Max Weber. São Paulo, Unesp.

SOARES, Fábio V. et al. (2006), Programas de Transferência de Renda no Brasil. Impactos sobre a Desigualdade. Trabalho apresentado no XXXIV Encontro Nacional de Economia da ANPEC, Salvador, 5-8 de dezembro. Disponível em http:/ / www.anpec.org. br/encontro2006/artigos / A06A156.pdf. Acessado em fevereiro de 2009.

DADOS - Revista de Ciências Sociais, Rio de Janeiro, vol. 58, n 4, 2015 


\section{Adalberto Cardoso}

SPOSITO, Marília P.; CORROCHANO, Maria C. (2006), “A Face Oculta da Transferência de Renda para Jovens no Brasil”. Tempo Social, vol. 17, no 2, pp. 141-172.

STANDING, Guy. (2011), The Precariat. The New Dangerous Class. London, Bloomsbury.

TROW, Martin. (1973), "Problems in the Transition from Elite to Mass Higher Education". Policies for Higher Education, OECD, Paris. Disponível em http:/ / files.eric.ed. gov/fulltext/ED091983.pdf.

VAN ZANTEN, Agnès. (2001), L'École de la Périphérie. Scolarité et Ségrégation en Banlieue. Paris, PUF.

VANDENBERGHE, Frédéric. (1999), Globalisation and Individualisation in Late Modernity. A Theoretical Introduction to the Sociology of Youth (mimeo). Disponível em http:/ / pronex.iesp.uerj.br/textos/youth.pdf.

ZALUAR, Alba. (2014), “Juventude Violenta: Processos, Retrocessos e Novos Percursos", in A. Cardoso (org.), Juventudes: Aspirações, Vulnerabilidades, Desigualdades (Brasil e França). Rio de Janeiro, Azougue. 


\section{RESUMO}

Metamorfoses da Questão Geracional: O Problema da Incorporação dos Jovens na Dinâmica Social

O artigo toma a teoria mannheimiana de gerações como fio condutor para propor uma interpretação sobre as metamorfoses da questão geracional no mundo desenvolvido, com o objetivo de pôr em perspectiva os padrões brasileiros de incorporação das novas gerações à vida coletiva. Procura-se contrapor um padrão eminentemente público (e republicano) de estruturação das oportunidades de vida das novas gerações, típico do mundo europeu, a outro, eminentemente privado (e mercantilizado), característico do Brasil, que estaria, porém, em processo de mudança nos últimos anos, ainda que muito lenta.

Palavras-chave: gerações; juventude; desigualdade; Brasil; Ocidente

\section{ABSTRACT \\ The Metamorphoses of the Generational Question: The Problem of the Incorporation of Youths in the Social Dynamic}

This article takes up the Mannheimian theory of generations as a guideline in proposing an interpretation of the metamorphoses of the generational question on the developed world, with the goal of putting into perspective patterns of incorporation of new generations into collective life in Brazil. It seeks to contrast the eminently public (and republican) pattern of the structuring of life opportunities of younger generations, typical of the European world, to another, more saliently private (and commoditized) pattern, characteristic of Brazil, with the latter nonetheless undergoing transformations, albeit slow, during recent years.

Keywords: generation; youth; inequality; Brazil; West 


\section{Adalberto Cardoso}

\section{RÉSUMÉ}

Métamorphoses de la Question Générationnelle: Le Problème de l'Incorporation des Jeunes à la Dynamique Sociale

Cet article fait de la théorie de Mannheim sur les générations le fil conducteur d'une interprétation des métamorphoses de la question générationnelle dans le monde développé, dans le but de mettre en perspective le contexte brésilien d'incorporation des nouvelles générations à la vie collective. On cherchera à distinguer un modèle éminemment public (et républicain) de structuration des opportunités offertes à la jeunesse, typique du monde européen, d'un autre, privé et mercantile, caractéristique de la réalité brésilienne, mais toutefois timidement engagé depuis quelques années dans un processus de changement.

Mots-clés: générations; jeunesse; inégalités; Brésil; Occident

\section{RESUMEN}

Metamorfosis de la Cuestión Generacional: El Problema de la Incorporación de los Jóvenes en la Dinámica Social

El artículo asume la teoría manheinmiana de generaciones como hilo conductor para proponer una interpretación sobre las metamorfosis de la cuestión generacional en el mundo desarrollado, con el objetivo de poner en perspectiva los patrones brasileños de incorporación de las nuevas generaciones a la vida colectiva. Se busca contraponer un patrón eminentemente público (y republicano) de estructuración de las oportunidades de vida de las nuevas generaciones, típico del mundo europeo, a otro, predominantemente privado (y mercantilizado), característico de Brasil que estaría, sin embargo, en proceso lento y paulatino de cambio en los últimos años.

Palabras clave: generaciones; juventud; desigualdad; Brasil; Occidente 